\title{
MORPHOLOGY AND PHYLOGENETIC RELATIONSHIPS OF FOSSIL SNAKE MACKERELS AND CUTLASSFISHES (TRICHIUROIDEA) FROM THE EOCENE (YPRESIAN) LONDON CLAY FORMATION
}

\author{
by HERMIONE T. BECKETT ${ }^{1,2}$ (D), SAM GILES ${ }^{1}$ (D), ZERINA JOHANSON ${ }^{2}$ (D) and \\ MATT FRIEDMAN ${ }^{1,3}$ \\ ${ }^{1}$ Department of Earth Sciences, University of Oxford, South Parks Road, Oxford, OX1 3AN, UK; hermione.beckett@earth.ox.ac.uk \\ ${ }^{2}$ Department of Earth Sciences, Natural History Museum, London, SW7 5BD, UK \\ ${ }^{3}$ Current address: Museum of Paleontology \& Department of Earth \& Environmental Sciences, University of Michigan, 1109 Geddes Ave, Ann Arbor, MI \\ 48109-1079, USA
}

Typescript received 9 November 2017; accepted in revised form 12 March 2018

\begin{abstract}
Gempylids' (snake mackerels) and trichiurids (cutlassfishes) are pelagic fishes characterized by slender to eel-like bodies, deep-sea predatory ecologies, and large fanglike teeth. Several hypotheses of relationships between these groups have been proposed, but a consensus remains elusive. Fossils attributed to 'gempylids' and trichiurids consist almost exclusively of highly compressed body fossils and isolated teeth and otoliths. We use micro-computed tomography to redescribe two three-dimensional crania, historically assigned to $\dagger$ Eutrichiurides winkleri and $\dagger$ Progempylus edwardsi, as well as an isolated braincase (NHMUK PV OR 41318). All from the London Clay Formation (Eocene, Ypresian), these specimens represent some of the oldest fossils identified as trichiuroids. We find that $\dagger$ Eutrichiurides winkleri does not show diagnostic characters of $\uparrow$ Eutrichiurides, and it is assigned to a new genus. To investigate the placement of these fossils
\end{abstract}

relative to extant lineages, we combine existing morphological character sets for 'gempylids' and trichiurids along with published mitogenomic data. Our analyses recover a monophyletic Trichiuridae nested within a paraphyletic 'Gempylidae'. The taxon formerly known as †Eutrichiurides winkleri is considered Trichiuroidea incertae sedis, while †Progempylus edwardsi and NHMUK PV OR 41318 are recovered within the 'gempylid' grade. Using previously published descriptions and character optimizations from our phylogenetic analyses we suggest possible placements for laterally compressed body fossils assigned to Trichiuroidea (†Argestichthys, $†$ Abadzekhia, $\dagger$ Chelifichthys, $\uparrow$ Anenchelum, $\dagger$ Eutrichiurides, $†$ Musculopedunculus).

Key words: Trichiuroidea, morphology, London Clay, Trichiuridae, Gempylidae, fossil.
'Gempylids' (snake mackerels) and trichiurids (cutlassfishes) are two closely related families of pelagic percomorph fishes. Typically, they have slender to eel-like bodies, deep-sea predatory ecologies and large fang-like teeth. These nominal families are only modestly diverse; 'gempylids' include 23 species in 16 genera, and trichiurids 32 species in 9 genera (Nakamura \& Parin 1993). For the past century, 'Gempylidae' and Trichiuridae have been closely associated with Scombridae (tunas and mackerels) and, less consistently, with Xiphoidei (billfishes). Regan (1909) recognized the divisions Trichiuriformes and Scombriformes (in addition to Luvariformes and Xiphiiformes, which are now associated with other groups) in a suborder Scombroidei. While a close affinity between 'gempylids' and trichiurids has long been recognized (here referred to as Trichiuroidea sensu Nakamura \& Parin 1993), the exact relationship between the families remains equivocal in light of both anatomical and molecular evidence. Some morphological (Johnson 1986; Potthoff et al. 1986; Carpenter et al. 1995) and molecular analyses support trichiuroid monophyly, with trichiurids nested within 'gempylids' (Orrell et al. 2006) or with reciprocally monophyletic trichiurids and gempylids (Betancur-R et al. 2013; Alfaro et al. 2018). However, others indicate trichiuroids are paraphyletic to (morphological: Collette et al. 1984; molecular: Miya et al. 2013) or polyphyletic within (Near et al. 2013; Betancur-R et al. 2017) a group with variable composition but which always contains scombrids. Despite these differences, two patterns consistently emerge in addition to the close 
association of trichiurids and 'gempylids'. First, trichiurids always form a clade. Second, 'gempylids' are typically interpreted as paraphyletic, either with respect to trichiurids (Johnson 1986; Potthoff et al. 1986; Carpenter et al. 1995; Orrell et al. 2006) or other groups (Collette et al. 1984; Miya et al. 2013; Near et al. 2013; but see Betancur-R et al. 2013, 2017). Unfortunately, many of these molecular studies are limited in their sampling of taxa (Near et al. 2013: two 'gempylids' and two trichiurids; Betancur-R et al. 2013: four 'gempylids' and six trichiurids; Betancur-R et al. 2017: six 'gempylids' and six trichiurids) or sequence data (e.g. mitochondrial genes only; Miya et al. 2013). Additionally, the most comprehensive morphological analyses of relationships have focused on either 'gempylids' (Russo 1983) or trichiurids (Gago 1998) or, when combined, have employed limited character sampling (ontogenetic characters only; Gago 1997).

Fossils identified as 'gempylids' and trichiurids consist almost exclusively of isolated teeth, otoliths, and highly compressed, effectively two-dimensional body fossils (Miya et al. 2013, SI text S2). The earliest putative remains assigned to each group are problematic. Nolf \& Stringer (1996) interpreted Late Cretaceous (Campanian) otoliths as belonging to 'gempylids', but similar in situ examples show that they derive from aulopiforms (Stringer et al. 2016; Schwarzhans et al. 2018). Isolated teeth from the early Paleocene (Danian) of Angola (Dartevelle \& Casier 1959) are attributed to the trichiurid †Eutrichiurides, but their affinities are also subject to question (see below). More secure evidence for the early history of trichiuroids derives from the body fossil record. The oldest articulated fossils interpreted as 'gempylids' are from early Eocene (early Ypresian) deposits, and include undescribed material from the Fur Formation of Denmark (Bonde 2008). Younger Eocene specimens include a three-dimensionally preserved skull of †Progempylus and an unnamed braincase from the London Clay Formation of the UK (Casier 1966; Monsch 2005), undescribed material of two taxa from Monte Solane, Italy (Gempylidae gen. indet., Gempylidae gen. indet. cf. Thrysitoides; Zorzin et al. 2011, figs 8-9; Giusberti et al. 2014, figs 5C, 6A-B) and Iranian material assigned to Epinnula and Thrysitoides (Arambourg 1967; originally interpreted as Oligocene, but see Afsari et al. (2014) for a reassessment of age). Post-Eocene 'gempylids' are represented by $\dagger$ Abadzekhia (Oligocene (Rupelian-Chattian) of the Caucasus and Germany; Bannikov 1985, 2005, 2010), †Chelifichthys (Miocene (Messinian) of Algeria; Carnevale 2006) and $\dagger$ Hemithyrsites (Miocene (Messinian) of Italy and Miocene (Burdigalian) of the Caucasus; Sauvage 1873; Daniltshenko 1960). Excluding isolated teeth, the oldest articulated skeletal remains placed in Trichiuridae are an incomplete skull assigned to †Eutrichiurides (Casier 1966) from the early Eocene (Ypresian) London Clay Formation of the UK, a fragmentary skull also assigned to †Eutrichiurides (Bonde et al. 2008) from the Lillebælt Clay of Denmark, and an as-yet undescribed specimen similar to †Anenchelum from roughly contemporaneous deposits of Monte Solane, Italy (Zorzin et al. 2011). Most other trichiurid body fossils are assigned to either †Anenchelum (Blainville 1818) or the extant Lepidopus (Blainville 1818) and are middle Eocene-Pliocene in age, but some distinctive fossil taxa have been recognized, most notably $\uparrow M u s c u-$ lopedunculus micklichi (Oligocene (Rupelian) of Germany; Parin \& Astakhov 2007).

Uncertainty surrounding the relationships of fossil 'gempylids' and trichiurids stems from a number of factors. First, fossil taxa, including those discussed above, have not been included in a formal, published phylogenetic analysis (but see a formal cladogram in an unpublished PhD by Monsch (2000) and informal placement, based on verbal argumentation, in Monsch \& Bannikov 2012, fig. 2). Second, morphological datasets for 'Gempylidae' and Trichiuridae rely heavily on soft-tissue and cranial characters (c. 80\%: Russo 1983; c. 50\%: Gago 1998). The former are almost impossible to obtain from fossils, and the latter challenging due to the prevalence of twodimensional fossils in which postcranial structure is clear but crania are often badly crushed. Third, available character lists target either 'gempylids' (Russo 1983) or trichiurids (Gago 1998) and the intrarelationships of those individual families, rather than sampling both extensively to explore their mutual relationships. This is particularly problematic given uncertainties in the relationships between these groups, which is amplified in the case of fossils that putatively exhibit unusual mosaics of 'gempylid' and trichiurid-like characters (e.g. †Argestichthys; Prokofiev 2002).

In this study, we combine existing morphological character sets for 'gempylids' and trichiurids along with published molecular sequence data and additional observations of extant taxa in order to infer phylogenetic placements for some of the earliest fossil trichiuroids. Specifically, we investigate a series of fossils from the Eocene (Ypresian) London Clay Formation of the UK: $\dagger$ Eutrichiurides winkleri, †Progempylus edwardsi, and an isolated braincase previously identified as a 'gempylid' (Fig. 1). These specimens represent nearly all threedimensionally preserved examples of trichiuroids (Casier 1966; Monsch 2005) with the potential to preserve many of the cranial features that feature prominently in anatomical analyses of living species. We present new descriptions of these specimens, based on a combination of external examination and micro-computed tomography $(\mu \mathrm{CT})$ scanning. In addition to analytically inferred placements for these three-dimensionally preserved 

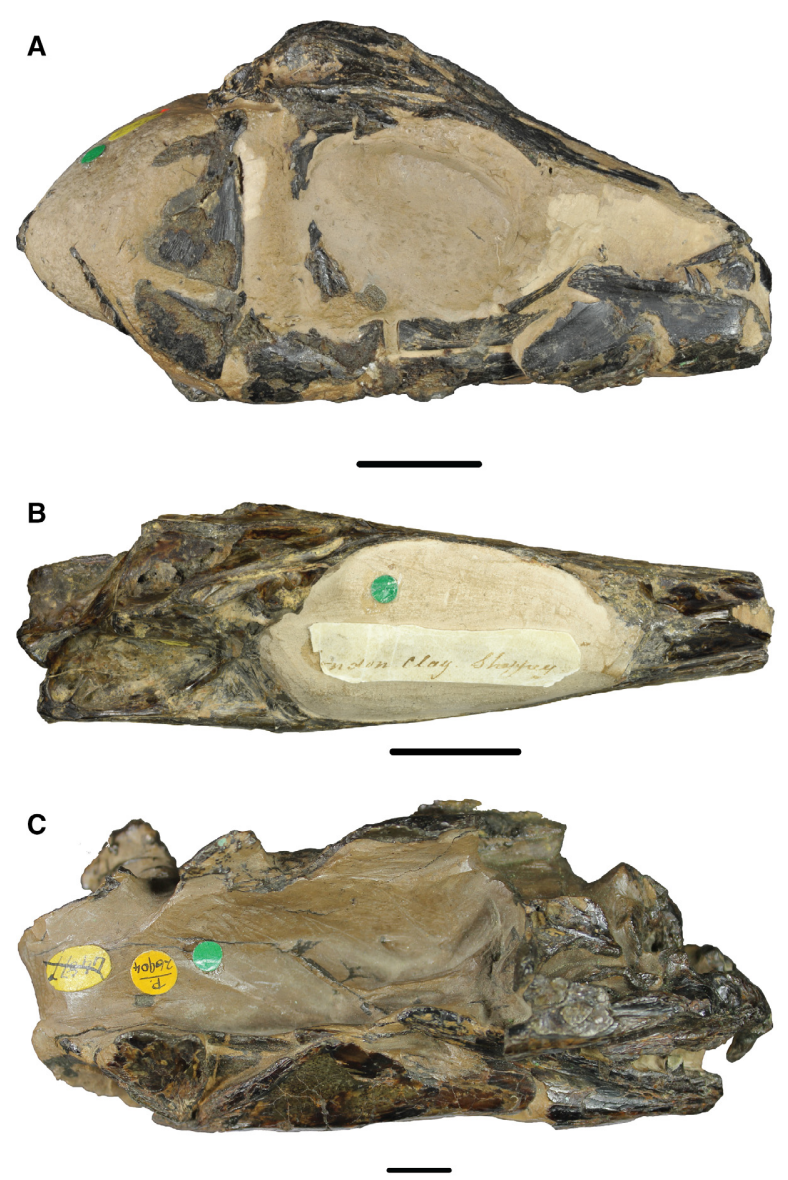

FIG. 1. Photographs of the fossil specimens. A, †Progempylus edwardsi (NHMUK PV OR 32388). B, NHMUK PV OR 41318. C, NHMUK PV P26904. All scale bars represent $10 \mathrm{~mm}$. Colour online.

London Clay specimens based on a morphological character matrix for Trichiuroidea, we provide possible placements of other fossil taxa associated with the group.

\section{MATERIAL AND METHOD}

Specimens examined

Below we list the specimens used in the course of this study. Both wet and dry specimens were studied for extant taxa, indicated with ${ }^{[\mathrm{W}]}$ and ${ }^{[\mathrm{D}]}$ respectively. Wet specimens were studied using radiography and $\mu \mathrm{CT}$, indicated by ${ }^{[\mathrm{R}]}$ and ${ }^{[\mathrm{C}]}$ respectively. Following Patterson \& Rosen (1977), the names of extinct taxa are preceded with a dagger symbol $(\dagger)$.

Trichiuroidea. Additional observations were made of extant Trichiuroidea based on descriptions by Nakamura
\& Fujii (1983), Russo (1983), Fujita (1990), Nakamura \& Parin (1993), and Gago (1998).

'Gempylidae'. NHMUK PV OR 41318 (Fig. 1B) an isolated braincase from the Eocene (Ypresian, 52-49 Ma) London Clay Formation, UK (Friedman et al. 2016); Gempylus serpens BMNH $44.670^{[\mathrm{D}]}$, FMNH $71423^{[\mathrm{W}, \mathrm{C}]}$; Hemithyrsites prometheus BMNH $44.650^{[\mathrm{D}]}$, BMNH 1906.9.8.149 $9^{[\mathrm{W}, \mathrm{R}]}$, UMMZ 250143 ${ }^{[\mathrm{W}, \mathrm{C}]}$; Lepidocybium flavobrunneum LACM $36320-1^{[\mathrm{W}, \mathrm{C}]}$; Nealotus tripes BMNH 2016.4.14.59 ${ }^{[\mathrm{W}, \mathrm{R}]}$; Neoepinnula orientalis BMNH 1986.9.8.164. ${ }^{[\mathrm{W}, \mathrm{R}]}$; Nesiarchus nasutus BMNH 1998.8.9.127.37-38 ${ }^{[\mathrm{W}, \mathrm{R}]}$, FMNH $71422^{[\mathrm{W}, \mathrm{C}]}$; Paradiplospinus gracilis BMNH 2009.5.18.74-75 $5^{[\mathrm{W}, \mathrm{R}]}, \quad \mathrm{BMNH}$ 2009.5.18.143 ${ }^{[\mathrm{W}, \mathrm{C}]}$; †Progempylus edwardsi NHMUK PV OR $32388^{[\mathrm{C}]}$ (Fig. 1A) a cranium from the Eocene (Ypresian, 52-49 Ma) London Clay Formation, UK (Friedman et al. 2016); Rexea prometheoides FMNH $120779^{[\mathrm{W}, \mathrm{C}]}$; Ruvettus pretiosus BMNH 44.620 ${ }^{[\mathrm{D}]}$, BMNH 1997.5.21.40 ${ }^{[\mathrm{W}, \mathrm{R}]}$, BMNH 1938.6.23 ${ }^{[\mathrm{W}, \mathrm{C}]}$; Thyrsites prometheus BMNH 99.1.16. ${ }^{[\mathrm{W}, \mathrm{R}]}$; Thyrsitoides marleyi $\mathrm{BMNH}$ 1986.9.8.147 ${ }^{[\mathrm{W}, \mathrm{R}, \mathrm{C}]}$.

Trichiuridae. NHMUK PV P $26904^{[\mathrm{C}]}$ (Fig. 1C) a cranium from the Eocene (Ypresian, 52-49 Ma) London Clay Formation, UK (Friedman et al. 2016); Aphanopus carbo BMNH 1899.1.16.5 [D], BMNH 1961.6.20.1 ${ }^{[\mathrm{W}, \mathrm{R}]}$, BMNH 2006.6.27.1 ${ }^{[\mathrm{W}, \mathrm{C}]}$; Benthodesmus simonyi $\mathrm{BMNH}$ 1972.1.10.64 ${ }^{[\mathrm{W}, \mathrm{R}, \mathrm{C}]}$; Eupleurogrammus glossodon $\mathrm{BMNH}$ 1955.5.13. $3^{[\mathrm{W}, \mathrm{R}]}$; Lepidopus caudatus BMNH $44.820^{[\mathrm{D}]}$, BMNH 1864.10.5.7 ${ }^{[\mathrm{W}, \mathrm{R}]}$, BMNH 1903.6.27.22 $2^{[\mathrm{W}, \mathrm{C}]}$; Lepturacanthus savala $\mathrm{BMNH}$ 51.19.27.14.3 ${ }^{[\mathrm{W}, \mathrm{R}]}$, UMMZ $219522^{[\mathrm{W}, \mathrm{C}]}$; Tentoriceps cristatus BMNH 1974.3.5.1-3 ${ }^{[\mathrm{W}, \mathrm{R}]}$, BMNH 1987.1.23-28 ${ }^{[\mathrm{W}, \mathrm{C}]}$; Trichiurus lepturus BMNH $44.850^{[\mathrm{D}]}$, BMNH 1897.12.1.343 ${ }^{[\mathrm{W}, \mathrm{R}]}$, UMMZ $219710^{[\mathrm{W}, \mathrm{C}]}$.

Pomatomidae. Pomatomus saltatrix studied from the literature (Leapley 1952) and UMMZ $111069^{[\mathrm{W}, \mathrm{C}]}$.

Scombridae. Gasterochisma melampus studied from the literature (Kohno 1984) and specimen photographs of AMNH 098426SD ${ }^{[D]}$.

\section{X-ray computed tomography}

Fossil specimens $\dagger$ Eutrichiurides winkleri and $\dagger$ Progempylus edwardsi were studied using $\mu \mathrm{CT}$ scanning. These had previously been mechanically prepared to expose external bones, and $\mu \mathrm{CT}$ presents an effective method of obtaining additional information on the internal anatomy of London Clay material (Beckett \& Friedman 2016). Extant taxa were scanned to obtain details of internal osteological anatomy not available from radiography or the literature. 
Fossil specimens and Recent BMNH specimens were scanned using the Metris X-Tek HMX ST $\mu$ CT scanner in the Imaging and Analysis Centre of the Natural History Museum, London. FMNH and UMMZ specimens were scanned using the Metris X-Tek XT H 225ST $\mu$ CT scanner at the CTEES facility in the Department of Earth and Environmental Sciences, University of Michigan. Scan settings are provided in Beckett et al. (2018). Tomogram stacks were segmented using Mimics Materialise v.16.0-19.0 × 64 (http://biomedical.materialise.com/mimics). High-resolution models produced in Mimics were exported as .ply files, then imported into Blender (https://blender.org) and rendered as two-dimensional images.

\section{Radiography}

Radiography of extant specimens from the Life Sciences collections of the Natural History Museum, London was undertaken in the Radiography Suite using the Solus Schall X-ray setup. All specimens were imaged at $3 \mu \mathrm{A}$ with a working distance of $75 \mathrm{~cm}$. Voltages and exposure times are given in Beckett et al. (2018, S1).

\section{Dataset assembly}

Morphology. We combined datasets for 'gempylids' (Russo 1983) and trichiurids (Gago 1997, 1998) to create a single morphological character matrix. Russo (1983) provided a character list, but no character-by-taxon matrix is presented in his thesis. However, we were able to reconstruct his character matrix based on his most parsimonious cladogram (Russo, 1983, fig. 47). Characters duplicated in source matrices were amalgamated, and indicated as such in the character list (Beckett et al. 2018). We also excluded characters that we could not interpret in comparative material due to ambiguity in the original character definitions (Gago 1998, pp. 4, 36, 60; Russo 1983, pp. 2, 7, 10, 27, 30, 32, 37, 55, 62, 69, 71, 72, 77, 78). We used published descriptions by Nakamura \& Fujii (1983), Russo (1983), Fujita (1990) and Gago (1998) to code characters for taxa from Russo (1983) not included in Gago (1998) and vice versa. Additional character states for extant taxa were obtained by studying dry specimens, radiographs and $\mu \mathrm{CT}$ data.

We also added five taxa to this combined dataset. In addition to the three fossil specimens described below (†Eutrichiurides winkleri, †Progempylus edwardsi and NHMUK PV OR 41318), we increased our sampling of outgroup lineages by including the pomatomid (bluefish) Pomatomus saltatrix (Leapley 1952) and early diverging scombrid Gasterochisma melampus (Kohno 1984) in addition to the scombrolabracid (longfin escolar) Scombrolabrax heterolepis, used in previous systematic studies. The resulting character matrix has 32 taxa coded for 144 characters. Of these, 103 relate to the skeleton $(73$ cranial, 38 postcranial), 3 refer to otoliths, 7 concern soft tissues, and 23 are developmental characters.

Individual ossifications are sometimes difficult to identify in fossils, particularly when they are closely sutured (as is often the case in the neurocranium). References to individual ossifications in our descriptions are based on visible sutures and positional comparisons with other taxa (both from the literature and first-hand observation).

Molecular data. From our morphological dataset, 17 taxa were matched with mitochondrial sequences from Miya et al. (2013; 12n3rRTn dataset, comprising 13596 base pairs). This molecular dataset represents whole mitogenomic sequences with the ND6 gene removed.

\section{Phylogenetic analysis}

Parsimony. We analysed the morphology only dataset using maximum parsimony as an optimality criterion in PAUP v.4.0a150 for Mac (Swofford 2003). We performed an heuristic search (addseq $=$ random, hold $=5$, nreps $=500$ ) with unweighted and unordered characters and the tree bisection and reconstruction strategy enabled. Nodal support was measured in PAUP by manual calculation of Bremer decay indices and by bootstrap analysis $\quad($ nreps $=100, \quad$ hold $=5$, search $=$ heuristic, addseq $=$ random $)$ retaining those clades with a frequency greater than $50 \%$. We rooted our networks on Pomatomus.

Bayesian. Both the morphology only and the combined morphological and molecular dataset were analysed in MrBayes v.3.2.6 (Huelsenbeck \& Ronquist 2001). A gamma distribution was specified for the morphologicalonly dataset. Molecular data were divided into five partitions, with a GTR substitution model specified for each with gamma-distributed rates (following Miya et al. 2013). The Mkv model was used for morphological data, with gamma-distributed rate variation among characters. Networks were rooted on Pomatomus saltatrix based on topologies presented in past studies (Orrell et al. 2006; Betancur-R et al. 2013, 2017). Monophyly of the trichiuroid ingroup was enforced. Each analysis ran for two independent runs of four chains, sampling every 500 generations for 15 million generations, and the first quarter of each run was discarded as burn-in. Convergence was indicated by average standard deviation of split 
frequencies $<0.01$, effective sample sizes $>200$ and visual inspection of the marginal probability distribution and trace of the analyses in Tracer v.1.6 (Drummond \& Rambaut 2007).

Institutional abbreviations. BMNH, Life Sciences collections, Natural History Museum, London, UK; FMNH, Division of Fishes, Field Museum, Chicago, USA; IRSNB, Institut Royal des Sciences Naturelles de Belgique, Brussels, Belgium; LACM, Natural History Museum of Los Angeles County, Los Angeles, USA; NHMUK, Earth Sciences collections, Natural History Museum, London, UK; UMMZ, Division of Fishes, University of Michigan Museum of Zoology, Ann Arbor, USA.

\section{SYSTEMATIC PALAEONTOLOGY}

\author{
TELEOSTEI Müller, 1845 \\ PERCOMORPHA Rosen, 1973 sensu Johnson \& Patterson, \\ 1993 \\ PELAGIA Miya \& Friedman in Miya et al. 2013 \\ TRICHIUROIDEA sensu Nakamura \& Parin, 1993 \\ 'GEMPYLIDAE' Gill, 1862
}

Genus †PROGEMPYLUS Casier, 1966

Type species. †Progempylus edwarsdi.

Diagnosis. As for type and only species.

$\dagger$ Progempylus edwardsi Casier, 1966

Figures 2-6

1901 Percidae? cf. Planesox vorax Woodward, p. 519.

1966 Progempylus edwardsi Casier, p. 250, pl. 40 fig. 2.

2005 Progempylus edwardsi Casier; Monsch, p. 449, fig. 4.

Holotype. NHMUK PV OR 32388, an articulated skull preserved in three dimensions.

Diagnosis. 'Gempylid' fish distinguished by the following combination of characters: braincase narrows above orbit and widens again anteriorly, lower jaw short with point of articulation with quadrate beneath the orbit, two pairs of vomerine teeth and lateral process on vomer.

Material. Type and only specimen, NHMUK PV OR 32388 , an historically prepared fossil that visibly preserves an articulated braincase, jaws, supsensoria and opercular series.

Occurrence. London Clay Formation, Isle of Sheppey, UK. Specimens from this locality are Ypresian in age and dated at 52-49 Ma (Friedman et al. 2016). The depositional setting is outlined in greater detail in Friedman et al. (2016).

Remarks. After being figured and described by Casier (1966), this specimen was revisited by Monsch (2005) who described the specimen briefly and associated it with 'gempylids'.

\section{Description}

$\dagger$ Progempylus edwardsi (NHMUK PV OR 32388) preserves the skull including the braincase, lower jaw, suspensorium, hyoid arch, gill-arch skeleton and opercular series.

Braincase. In dorsal view the neurocranium is narrow and long, approximately half as wide anteriorly as posteriorly. The paired frontals (Figs 2A, 3A) form the majority of the anterior portion of the skull roof. They are constricted above the orbit, but broken anteromedially such that it is not possible to discern the medial suture of the frontals with the mesethmoid. Narrow ridges ornament the frontals, and radiate from a point above the orbit. The supraorbital sensory canal extends through the frontal in an enclosed tube, branching twice and exiting the frontals via three branches. The first branch is directed medially in the posterior portion of the frontals and is visible as a large pore in the pineal region. The second offshoot exits the bone in a pore close to the medial suture of the frontals above the orbit. The main line continues anteriorly and exits the frontals in a small pore anterior to the orbit that is aligned with a groove that extends to the anterior margin of the frontal (Fig. 2A). The frontals are bordered posteriorly by the supraoccipital, parietals, pterotics and sphenotics. An elongate supraoccipital is bordered by the epiotics posteromedially and the parietals anteromedially. The supraoccipital ridge bifurcates, extending anteriorly to the level of the orbit. The parietals suture with the frontals anteriorly, and form part of the epiotic ridge, suturing with the pterotic laterally. The pterotic is elongate with a large ridge. The suture between the parietals and the pterotic can be traced posteriorly to the mid-point of the pterotic shelf. Laterally the pterotic sutures with the sphenotic, which forms the posterior margin of the orbit. The epiotic meets the posteromedial margin of the parietals and the lateral margin of the supraoccipital. A clear suture is visible posteriorly between the epiotic and the exoccipitals. The small intercalar is visible dorsally. It has a curved anterior margin that meets the exoccipitals anteromedially and the posterior margin of the pterotic anterolaterally.

In lateral view (Figs 2B, 3B) the neurocranium is deepest posteriorly, the parasphenoid curves dorsally to suture with the posterior margin of the vomer. The vomer is widest anteriorly where it meets the mesethmoid. Wings on either side of the vomer extend dorsolaterally from behind the vomerine teeth to the point of articulation with the parasphenoid. The vomer bears two pairs of teeth, which are small and posteriorly recurved. The anterior tooth is smaller than the posterior. Posteriorly the parasphenoid overlaps and sutures to the basioccipital. At the posterior margin of the orbit, the strut-like lateral 

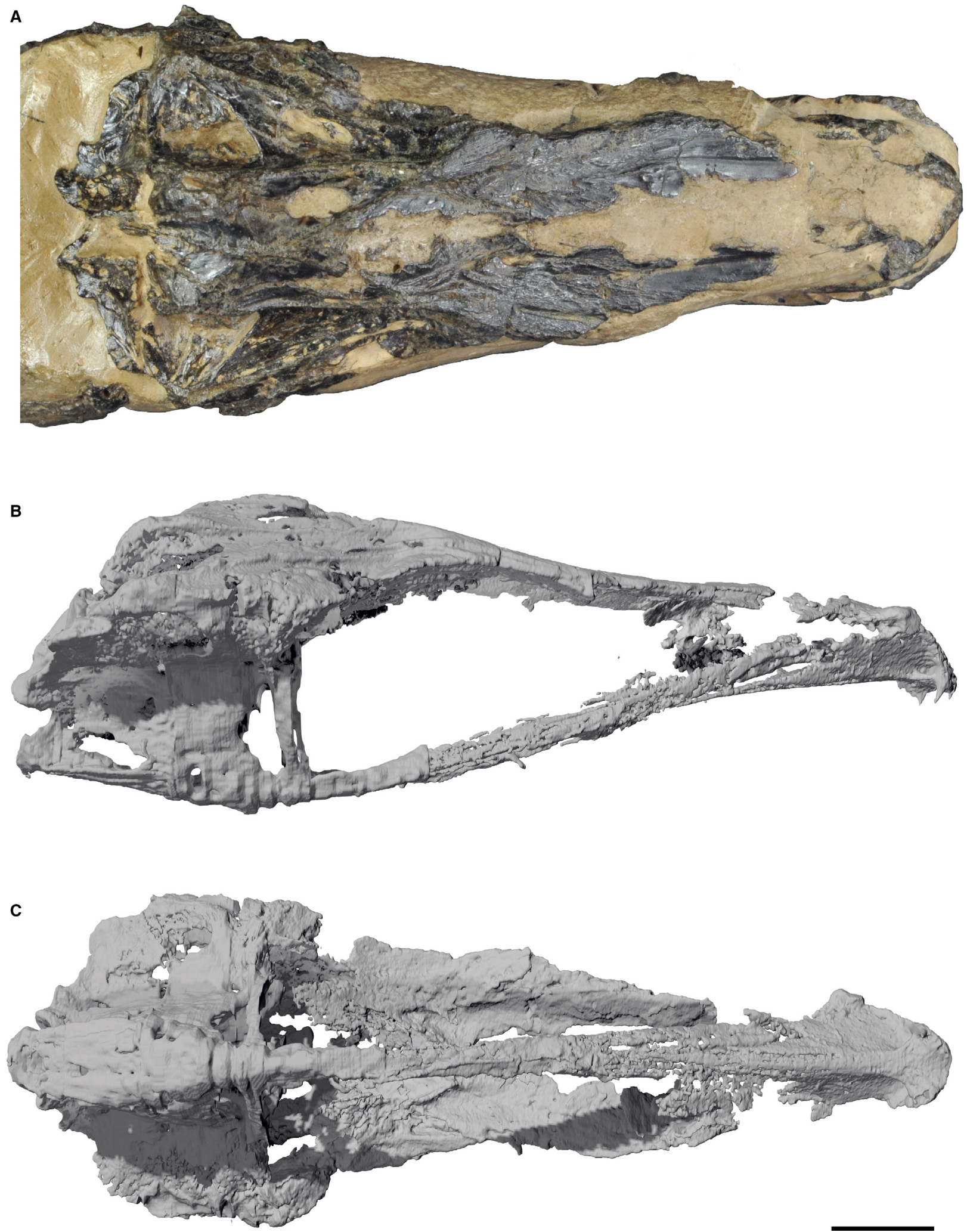

FIG. 2. The braincase of $\dagger$ Progempylus edwardsi (NHMUK PV OR 32388). A, specimen photograph, dorsal view. B-C, rendering in: $\mathrm{B}$, lateral; C, ventral view. Scale bar represents $10 \mathrm{~mm}$. Colour online. 

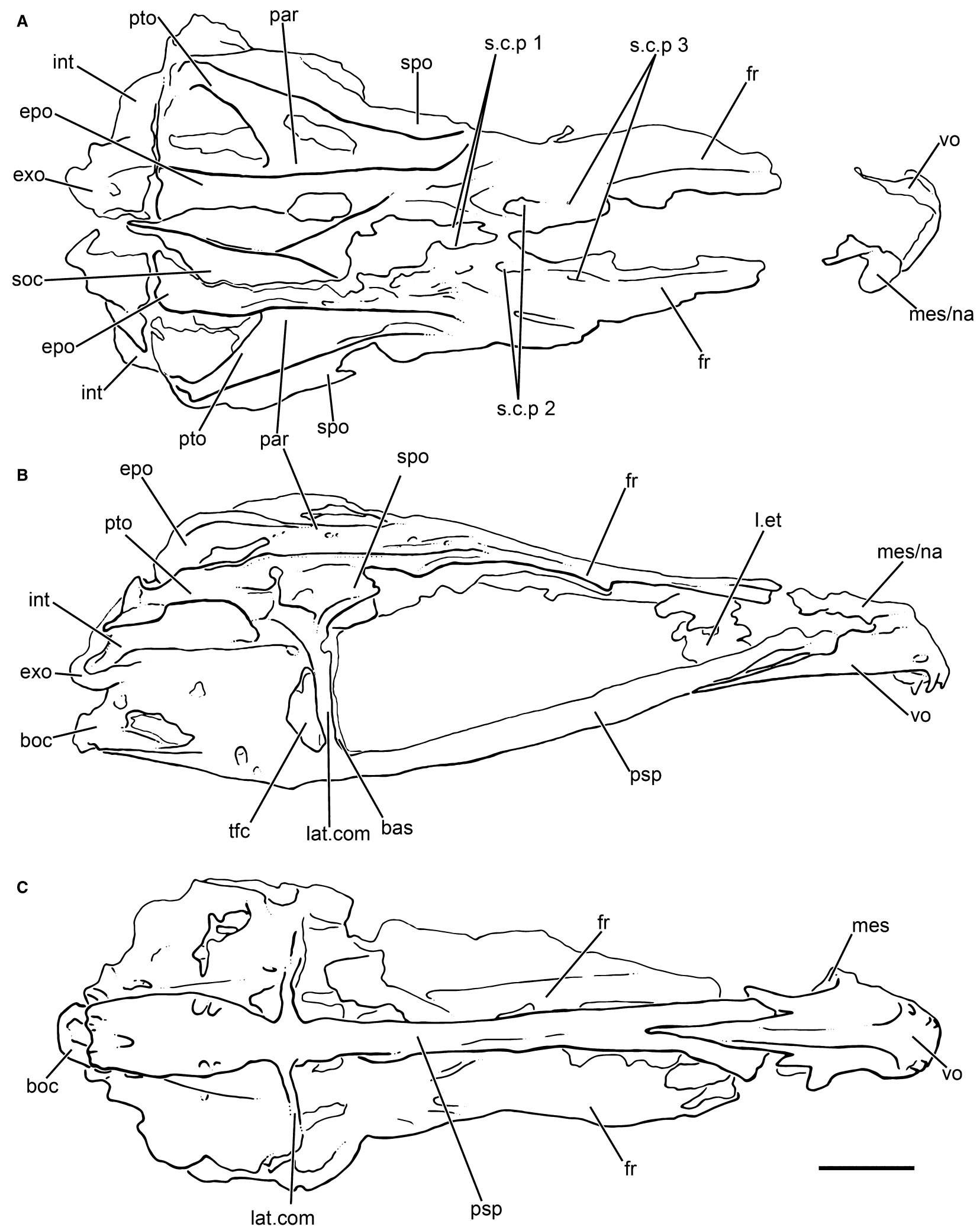

FIG. 3. The braincase of $\dagger$ Progempylus edwardsi (NHMUK PV OR 32388), drawings in: A, dorsal; B, lateral; C, ventral view. Abbreviations: bas, basisphenoid; boc, basioccipital; epo, epiotic; exo, exoccipitals; fr, frontal; int, intercalar; lat.com, lateral commissure; 1.et, lateral ethmoid; mes, mesethmoid; na, nasal; par, parietal; psp, parasphenoid; pto, pterotic; s.c.p.1-3, supraorbital canal pores 1-3; soc, supraoccipital; spo, sphenotic; tfc, trigeminal facial chamber; vo, vomer. Scale bar represents $10 \mathrm{~mm}$. 
A

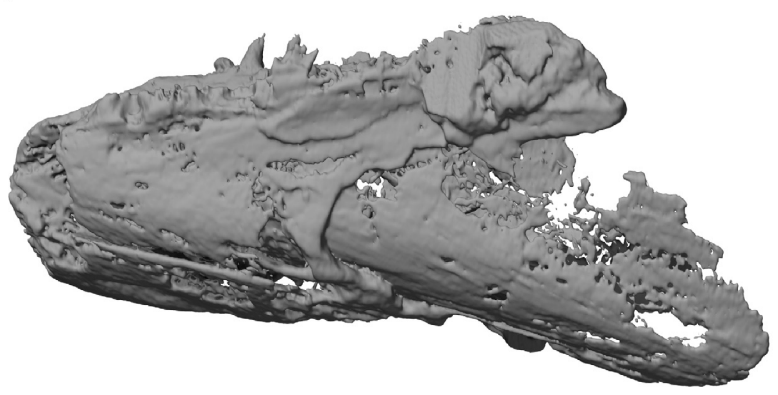

B

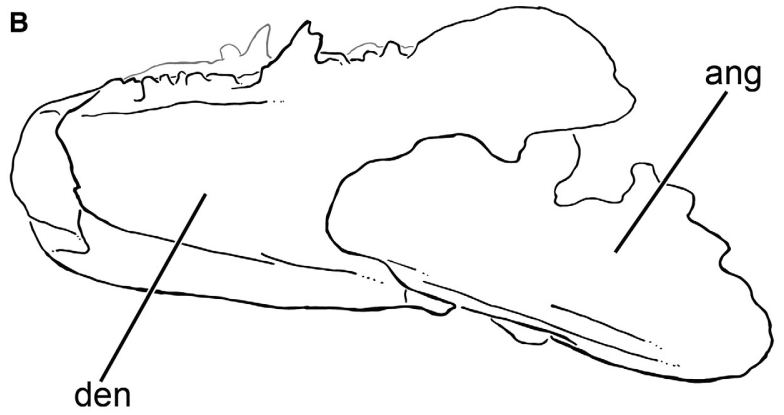

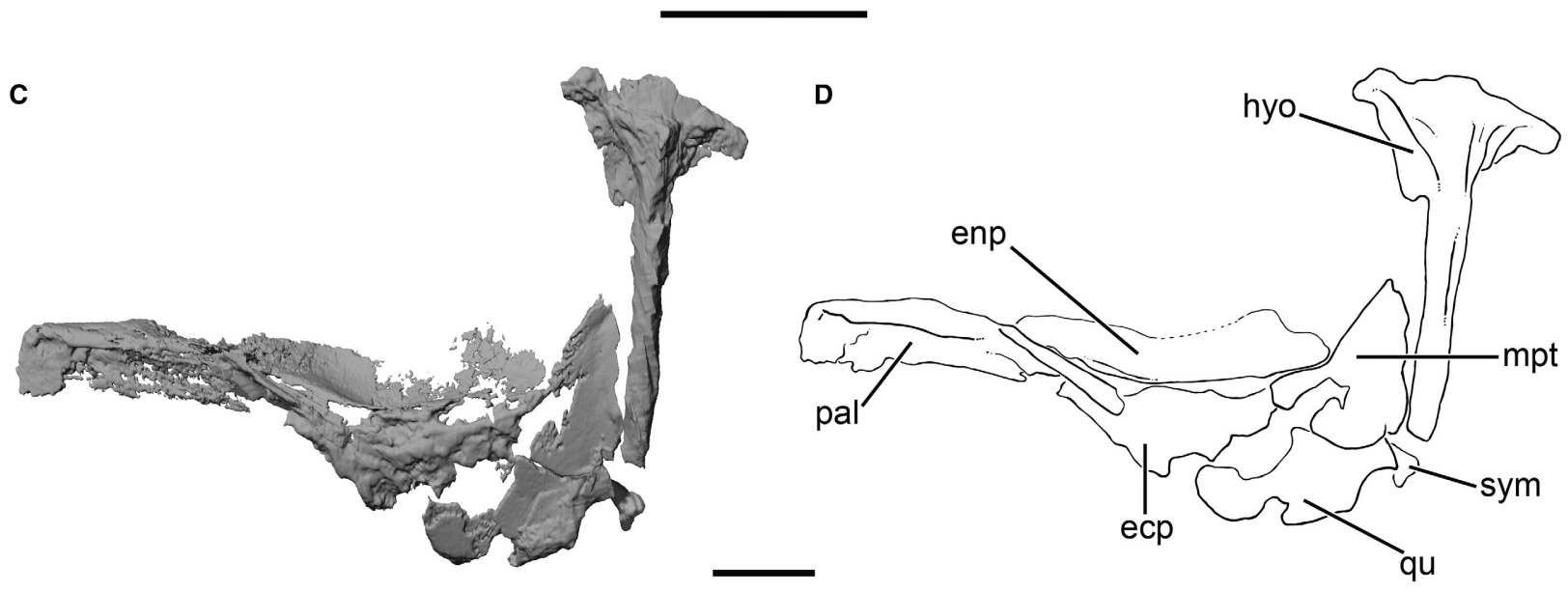

$\mathbf{E}$

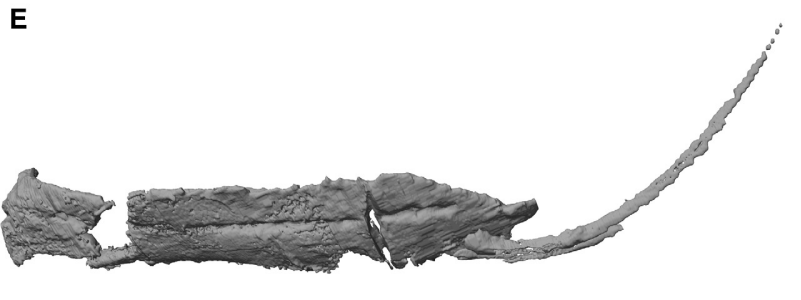

$\mathbf{F}$

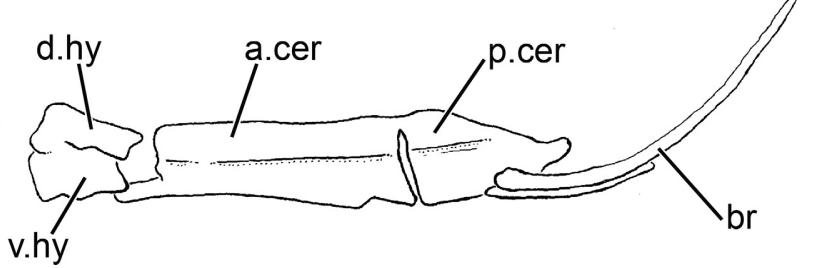

FIG. 4. †Progempylus edwardsi (NHMUK PV OR 32388). A-B, lower jaws in left lateral view; A, rendering; B, drawing (components of right mandible shown lighter). C-D, suspensorium in left lateral view; C, rendering; D, drawing. E-F, hyoid arch in left lateral view; E, rendering; F, drawing. Abbreviations: a.cer, anterior ceratohyal; ang, anguloarticular; br, branchiostegal; den, dentary; d.hy, dorsal hypohyal; ecp, ectopterygoid; enp, endopterygoid; hyo, hyomandibula; mpt, metapterygoid; pal, palatine; p.cer, posterior ceratohyal; sym, symplectic; qu, quadrate; v.hy, ventral hypohyal. Scale bars represent $10 \mathrm{~mm}$.

commissure defines the margin of a large trigeminal facial chamber (Fig. 3B).

Jaws. The lower jaw is short and deep, even accounting for missing bone at the anterior and posterior margins (Fig. 4A, B). The dentary exclusively forms the dorsal margin and contributes to the ventral margin of the jaw, with the anguloarticular inserted into the notch-like excavation in the posterior margin of the dentary. A series of small teeth are borne on the dorsal margin of the mandible, with three preserved on the right dentary and the base of three or four on the left. These teeth are relatively similar in size and evenly spaced along the jaw. The ventral-posterior margin of the lower jaw and its articulation with the quadrate appear to be missing, as the metapterygoid and fragmentary quadrate are preserved posterior to the preserved portion of the lower jaw. No components of the dermal upper jaw are preserved.

Suspensorium. The suspensorium comprises the palatine, ectopterygoid, endopterygoid, metapterygoid, quadrate, hyomandibula and symplectic (Fig. 4C, D). In lateral view the palatine consists of an elongate dorsal ridge and a ventral plate-like expansion. The lower margin of the ventral ridge is jagged but no obvious teeth are visible. The anterior process of the dorsal ridge is 
FIG. 5. Dorsal view of the gill arches of $\dagger$ Progempylus edwardsi (NHMUK PV OR 32388). A, rendering. B, drawing. Abbreviations: cb, ceratobranchial; eb, epibranchial; hb, hypobranchial; pb, pharyngobranchial; u, urohyal. Scale bar represents $10 \mathrm{~mm}$.

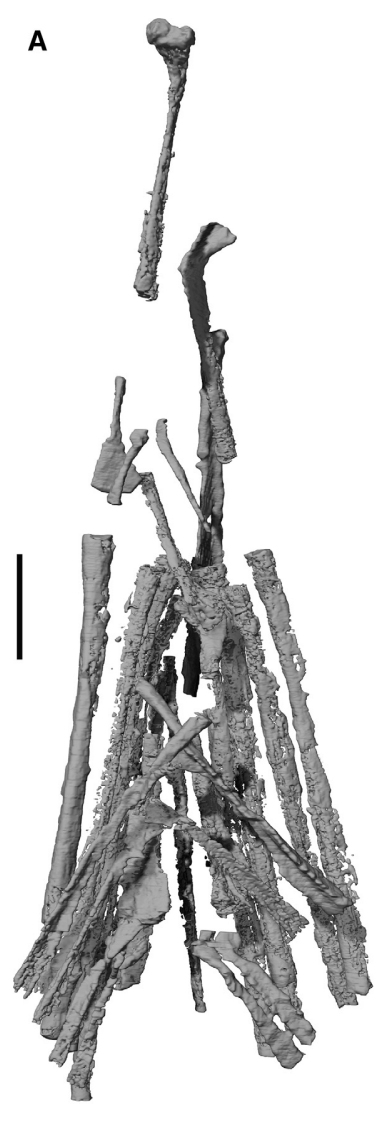

hooked and expanded medially, articulating posteriorly with the anterior margin of the endopterygoid, which is oval in shape, pointed anteriorly and concave dorsally. The ectopterygoid is poorly preserved and highly pyritized. On the left side of the specimen, a thin lamina of bone on the internal surface of the quadrate may also represent a fragment of ectopterygoid. A broad, flat metapterygoid with a posterodorsal extension sits anterior to the hyomandibular shaft, although the nature of the contact between the two bones is obscured by pyrite. The ventral margin of the metapterygoid articulates with the dorsal margin of the quadrate. The hyomandibula is fragmentary on the right side of the specimen, with only the anterodorsal head and a small ventral extension that articulates with the metapterygoid preserved. More complete on the left side, the hyomandibula has a flat dorsal head and long, slender ventral shaft. The dorsal head has two articular areas: an anterior projection that articulates with the sphenotic, and a posterior expansion articulating with the lateral margin of the braincase beneath the pterotic. The opercular process extends directly perpendicular to the ventral shaft of the hyomandibula. The quadrate is preserved as a fragment on both sides and its shape cannot be discerned. The symplectic is small and elongate.

Hyoid arch. The dorsal and ventral hypohyals are tightly bound. Each hypohyal is rectangular individually, but the dorsal and ventral components are tightly bound to form a square (Fig. 4E, F). The anterior ceratohyal is approximately three times the length of the hypohyals, and bears a narrow, longitudinal groove on its lateral surface. There is no ceratohyal window. The posterior ceratohyal is as deep as the anterior ceratohyal, but shorter in length. It tapers to a posterior point, forming a triangular shape. The anterior and posterior ceratohyals join in an interdigitated suture. Two narrow branchiostegals articulate with the posterior ceratohyal. Additional elements of the branchiostegal series are not apparent.

Gill skeleton. The gill skeleton is well preserved and largely in articulation, particularly posteriorly (Fig. 5). It preserves the urohyal, hypobranchials $1-3$, ceratobranchials $1-5$, epibranchials $1-4$ and pharyngobranchial 3 . Pharyngobranchial 1 is preserved only on the left side.

Hypobranchial 1 is preserved on both sides of the specimen, although both elements have been rotated out of life position. It is elongate with a large laterally-directed anterior head. Hypobranchial 2 is preserved most completely on the left side and has been rotated posteriorly. It is long and straight with an anteriorly expanded head of a similar size to hypobranchial 1. A fragment of bone on the right side occupies the expected position of hypobranchial 2. Hypobranchial 3 is well preserved on the left side, with a broad posterior expansion that is triangular in shape and extends anteriorly. The right hypobranchial 3 has been rotated posteriorly and is missing the elongate anterior expansion.

Ceratobranchials $1-5$ are elongate and straight with a groove extending the length of the ventral surface. Ceratobranchials 1-4 

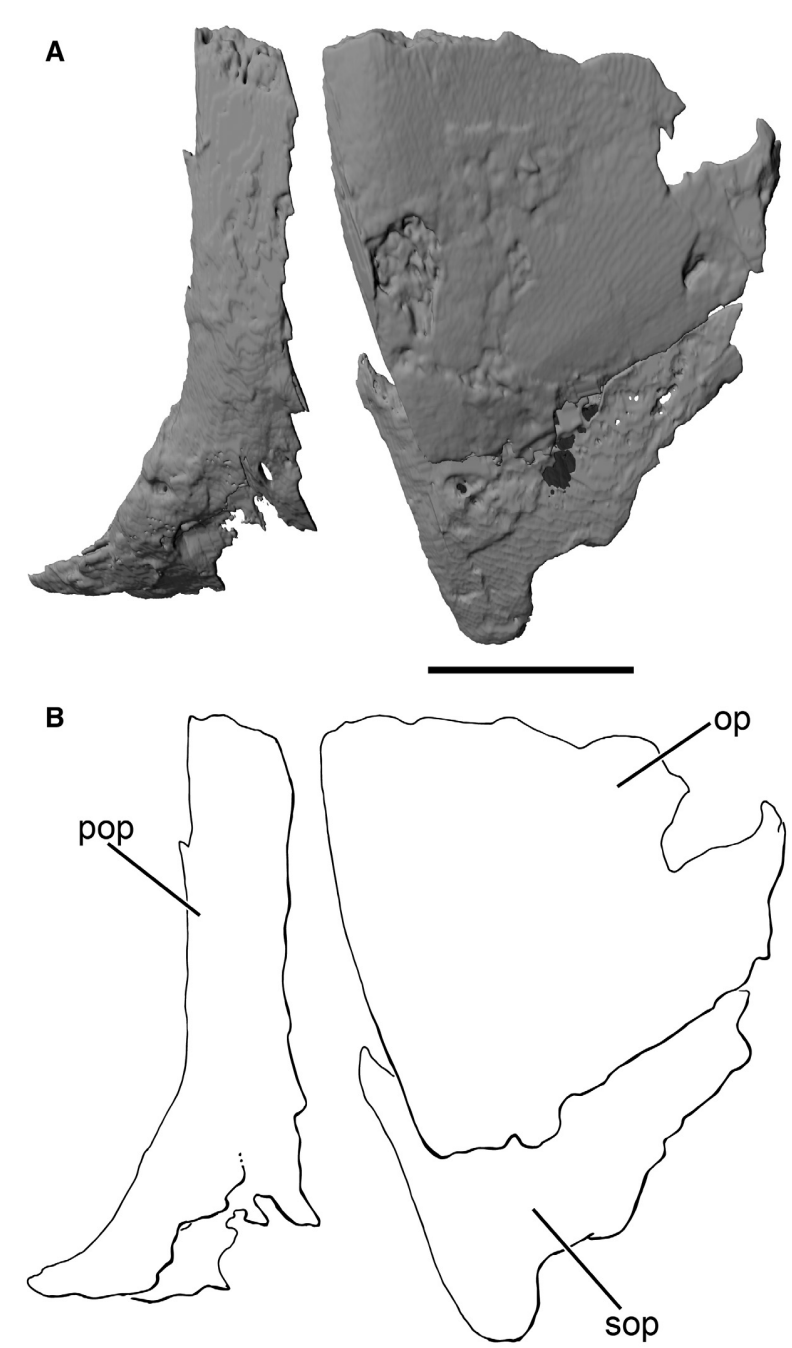

FIG. 6. Left lateral view of the opercular series of $\dagger$ Progempylus edwardsi (NHMUK PV OR 32388). A, rendering. B, drawing. Abbreviations: op, operculum; pop, preoperculum; sop, suboperculum. Scale bar represents $10 \mathrm{~mm}$.

are of approximately equal length but ceratobranchial 5 is only two-thirds the length of the other ceratobranchials and meets its antimere anteriorly. Ceratobranchial 5 is also slightly wider than ceratobranchials 1-4, expanding ventrally so the groove faces medially. No teeth are visible on the ceratobranchials.

Epibranchials 1-4 are elongate, curve medially and become progressively smaller from epibranchial 1 to epibranchial 4 . Each epibranchial bears a groove on its dorsal surface. Epibranchial 1 widens into a dorsolateral process one-third of the way along its length from the anterior margin. Epibranchial 2 lacks a process but is expanded anteriorly to form a flat triangular shaped head, and epibranchials 3 and 4 are also expanded slightly anteriorly. Epibranchial 3 has no associated processes, while the left epibranchial 4 shows a dorsal process.

Pharyngobranchial 1 is small and rod like with a small anterior head. It is preserved only on the left side, shifted anteriorly from its presumed life position. Pharyngobranchial 3 is equal in length to hypobranchial 2 but wider posteriorly, forming a shallow concavity in dorsal view. The ventral surface of the right pharyngobranchial 3 is rough, suggesting the possible presence of a sutured toothplate, although this is not clearly preserved. The urohyal is plate-like, triangular in lateral view, and anteriorly tapers to a trapezoidal head. The ventral margin of the urohyal has a small lateral expansion about the midline.

Opercular series. The opercular series consists of the preoperculum, operculum and suboperculum (Fig. 6). The preoperculum curves anteroventrally and is widest at the angle of the bone, with a weakly convex posterodorsal margin. The operculum and suboperculum are approximately triangular in shape, with the suboperculum smaller and positioned medio-ventrally to the operculum. A circular facet for articulation with the hyomandibula is preserved on the medial surface of the right operculum, and completely covered by a plate-like lateral process in lateral view. The operculum has a large notch on its posterodorsal margin. The ventral posterior margin of the notch forms a point at the posterodorsal corner of the operculum.

\section{'GEMPYLIDAE' incertae sedis Figures 7-8}

1966 cf. Eutrichiurides Casier, p. 249, text fig. 56, pl. 24 fig. 3.

2005 Gempylinae? incertae sedis Monsch, p. 449, fig. 5.

Material. NHMUK PV OR 41318, three-dimensionally preserved braincase.

Occurrence. London Clay Formation, Isle of Sheppey, UK. Specimens from this locality are Ypresian in age and dated at 52-49 Ma. The depositional setting is outlined in greater detail in Friedman et al. (2016).

Remarks. An historically prepared braincase referred to $\dagger$ Eutrichiurides by Casier (1966) and then to 'Gempylidae' by Monsch (2005), this specimen is incomplete anteriorly but is otherwise well-preserved. The specimen is characterized by an elongate braincase with frontals that narrow appreciably above the orbits, prominent parietal and epiotic ridges, a supraoccipital ridge that bifurcates on the supraoccipital, and exoccipitals that extend posteriorly. Comparisons with NHMUK PV P26904 are limited by the small amount of overlap in the regions of the braincase preserved in the specimens. Characters differentiating NHMUK PV OR 41318 from NHMUK PV P26904 are: vomer does not extend markedly posterior to the lateral ethmoids (vomer in NHMUK PV P26904 extends over half the length of the neurocranium to the midpoint of the orbit); strong ornament not apparent on frontal (compared to the ornament on the right 
fragmentary frontal in NHMUK PV P26904). NHMUK PV OR 41318 also shows clear differences from $\uparrow$ Progempylus edwardsi: parasphenoid and vomer are approximately parallel to the frontals in NHMUK PV OR 41318 (the parasphenoid and vomer curve dorsally in lateral view in †Progempylus edwardsi); basioccipital and exoccipitals extend far posterior to the rear margin of the intercalar and pterotic (in †Progempylus edwardsi the basioccipital and exoccipitals do not exhibit such a marked posterior projection relative to the intercalar and pterotic).

\section{Description}

Braincase. In dorsal view the paired frontals are elongate, narrowing medially above the orbit (Figs $7 \mathrm{~A}, 8 \mathrm{~A}$ ). In the pineal region of the frontals the pores for the medial branch of the supraorbital canal are visible. The frontals suture anteriorly with the mesethmoid which narrows anteriorly and is broken laterally. In lateral view the mesethmoid extends to meet the dorsal surface of the vomer (Figs 7B, 8B). The lateral ethmoids extend laterally beyond the mesethmoid and the frontals in dorsal view, and meet the posterior margin of the vomer and mesethmoid in lateral view. The posterior margin of the frontals sutures to the supraoccipital, which bears the supraoccipital crest (Figs 7A, 8A). Dorsally the supraoccipital crest is broken but is well developed and extends posteriorly over the exoccipitals. The parietals lie lateral to the supraoccipital. Posteromedially, the frontals are bordered by the sphenotic. The sphenotic forms the posterior margin of the orbit and sutures with the pterotic posteriorly. The parietals suture to the pterotic laterally and the epiotic posteriorly. The pterotic has a pronounced shelf and a well-developed pterotic ridge, almost the same height as the epiotic ridge in lateral view. In dorsal view the epiotics are approximately round and suture with the intercalar and exoccipitals posteriorly. The intercalar is visible on the dorsal surface but is small, being larger on the ventral surface of the neurocranium, suturing with the sphenotics laterally and the basioccipital medially. The exoccipitals are kidney-shaped in lateral view. The basioccipital sutures to the underside of the exoccipitals and is concave in posterior view. In lateral view the basioccipital sutures to the dorsal side of the parasphenoid anteroventrally and the posterior side of the prootic anteriorly (Figs 7B, 8B). A ventrally placed foramen marks the exit of the vagus nerve from the exoccipital. In both lateral and ventral view the prootic is visible and connects the parasphenoid to the medial margin of the sphenotics. The lateral margin of the trigeminal facial chamber is defined by the strut-like lateral commissure, which forms the anterior margin of the prootic. At the junction of the parasphenoid and the prootic is the foramen for the internal carotid. The parasphenoid, which meets the basisphenoid posteriorly, extends anteriorly to the posterior margin of the vomer and meets this along a ' $v$ '-shaped contact at the posterior point of the lateral ethmoids (Figs 7C, 8C). The anterior tip of the vomer is missing and it is not possible to determine if teeth were present.
TRICHIUROIDEA incertae sedis

Genus $†$ MACROYNIS nov.

LSID. urn:lsid:zoobank.org:act:28EAA039-9656-40B7-8EE90098BBA9FD0E

Derivation of name. Macro, long, large; ynis, vomer; meaning long vomer in Greek.

Type species. Macroynis casieri sp. nov.

Diagnosis. As for type and only species.

$\dagger$ Macroynis casieri sp. nov. Figures 9-11

1966 Eutrichiurides winkleri Casier; Casier, p. 244, textfigs 55-56, pl. 23 figs 2-5.

2005 Eutrichiurides winkleri Casier; Monsch, p. 447, fig. 3.

LSID. urn:lsid:zoobank.org:act:FD07E026-37DF-4A68-ACE7EB07EB19EF82

Derivation of name. Specific name honours Edgard Casier, who first described the specimen.

Holotype and only specimen. NHMUK PV P26904 is an historically prepared, incomplete isolated skull from the London Clay of Sheppey, UK (for a review of depositional setting and age see Friedman et al. 2016). The braincase of this specimen is highly fragmented, particularly the dorsal surface.

Diagnosis. Trichiuroid fish distinguished by the following combination of characters: elongate vomer extending markedly behind the lateral ethmoid, single large premaxillary fang, anterior tooth on dentary in line with other teeth, anteroposteriorly abbreviated hypohyals located greatly anterior to the anterior ceratohyal, presence of a ceratohyal window in anterior ceratohyal, palatine triangular and ventrally extended in lateral view.

Occurrence. London Clay from the Isle of Sheppey, UK. Specimens from this locality are Ypresian in age and dated at 52-49 Ma. The depositional setting is outlined in greater detail in Friedman et al. (2016).

\section{Remarks}

The holotype of $\dagger$ Eutrichiurides delheidi, the type species of $\dagger$ Eutrichiurides (Casier 1944), comprises a dentary, 

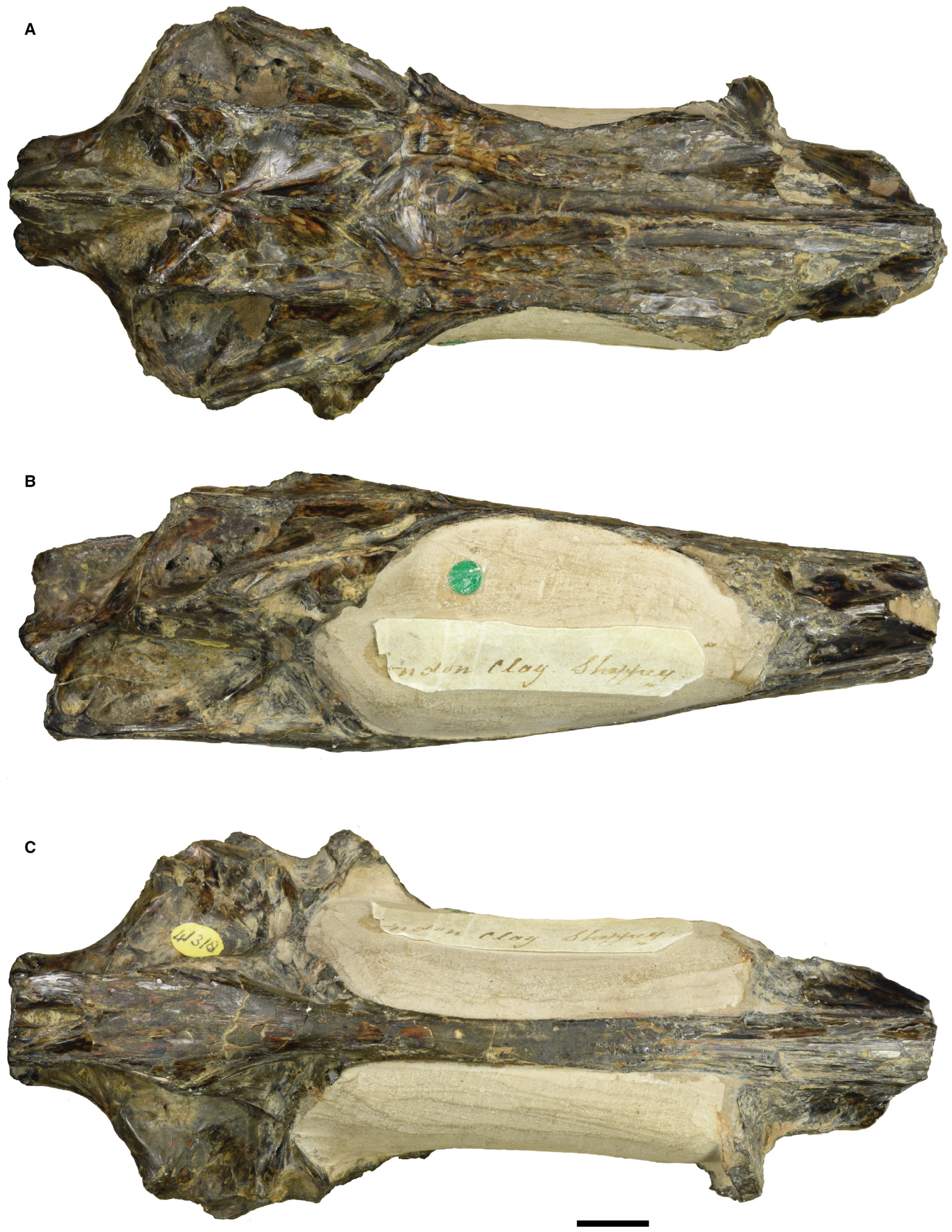

FIG. 7. The braincase of NHMUK PV OR 41318 (Gempylidae incertae sedis); photographs in: A, dorsal; B, lateral; C, ventral view. Scale bar represents $10 \mathrm{~mm}$. Colour online. 


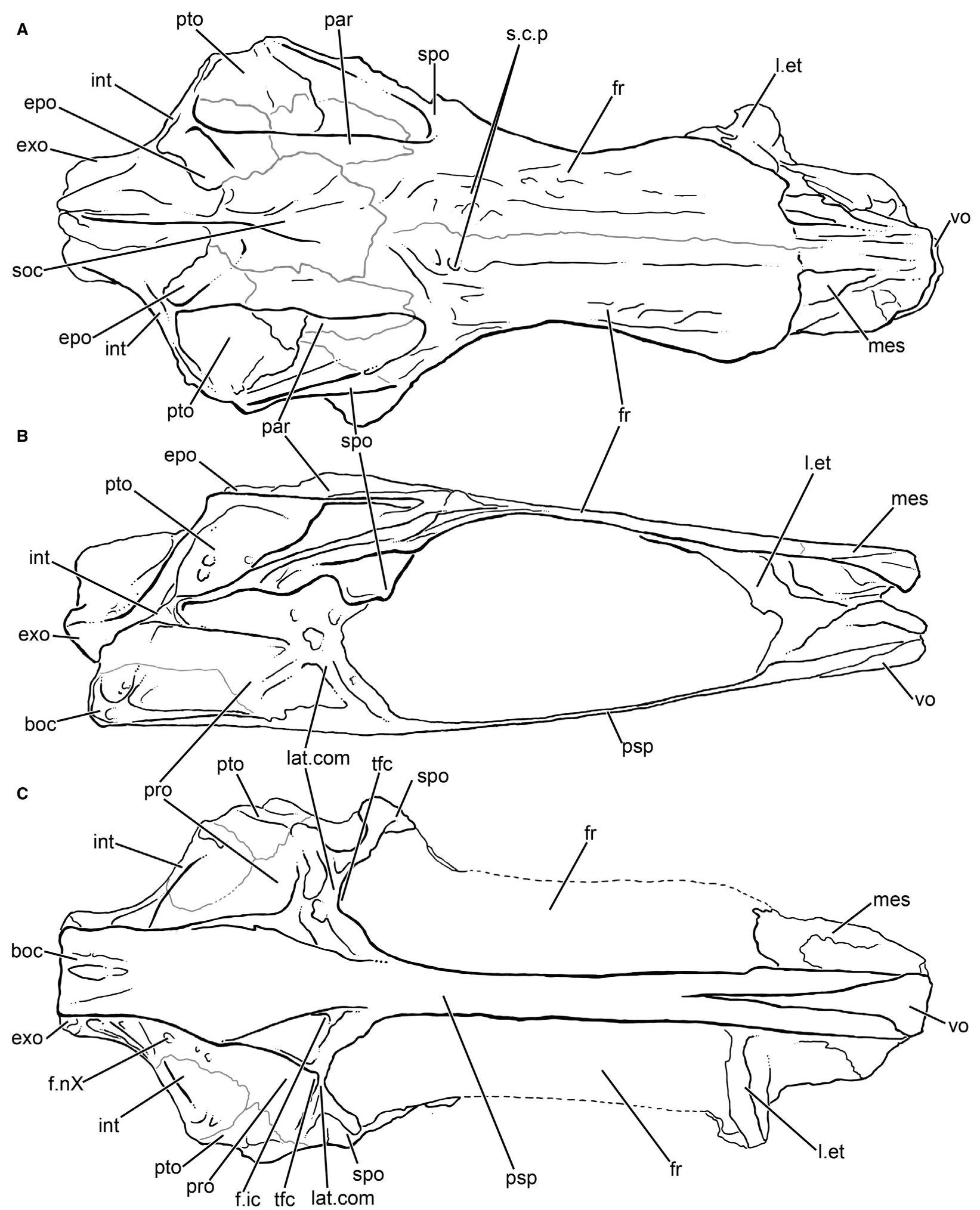

FIG. 8. The braincase of NHMUK PV OR 41318 (Gempylidae incertae sedis); drawings in: A, dorsal; B, lateral; C, ventral view. Abbreviations: boc, basioccipital; epo, epiotic; exo, exoccipitals; f.ic, foramen for internal carotid; f.nX, foramen for the vagus nerve (X); fr, frontal; int, intercalar; lat.com, lateral commissure; l.et, lateral ethmoid; mes, mesethmoid; par, parietal; pro, prootic; psp, parasphenoid; pto, pterotic; s.c.p, supraorbital canal pore; soc, supraoccipital; spo, sphenotic; tfc, trigeminal facial chamber; vo, vomer. Scale bar represents $10 \mathrm{~mm}$. 

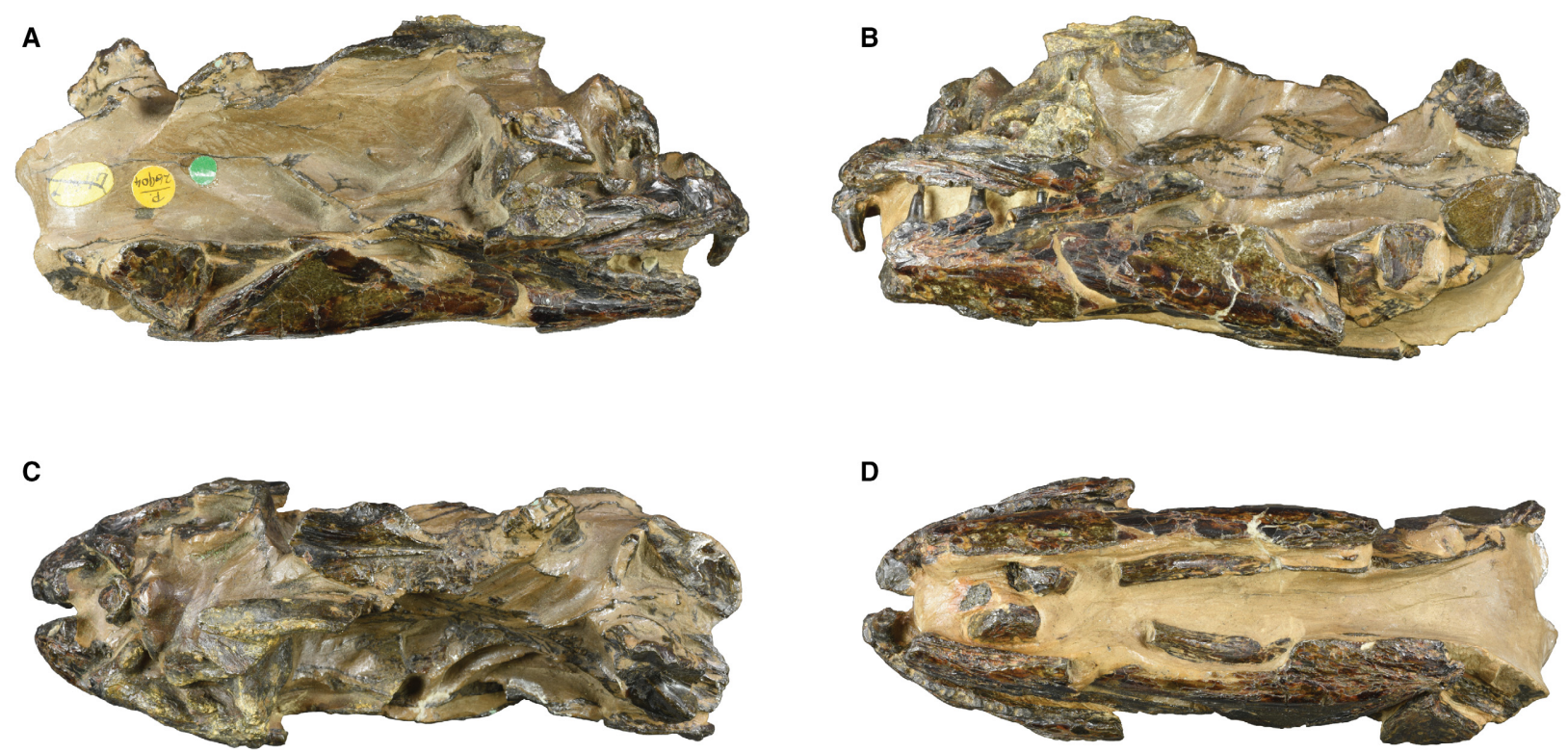

FIG. 9. Photographs of the skull of $\uparrow$ Macroynis casieri (NHMUK PV P26904) in: A, right lateral; B, left lateral; C, dorsal; D, ventral view. Scale bar represents $10 \mathrm{~mm}$. Colour online.

premaxilla and series of teeth belonging to a single individual (Leriche 1908; pl. 25 figs 1-2) from the Oligocene (Rupelian) Boom Clay of Belgium. Casier (1944, 1946, 1966) subsequently attributed isolated teeth removed from $\dagger$ Trichiurides to $\dagger$ Eutrichiurides. He reinterpreted teeth retained within the former genus as belonging to a gadiform. These isolated dentitions have a tortuous taxonomic history, featuring associations with lepisosteids (Woodward 1891) and lophiids (Leriche 1905) in addition to the trichiurid interpretation advocated by Casier and others (Winkler 1876; White 1931). It is from some of these isolated dentitions that Casier (1946) erected $\dagger E$. winkleri (type series: IRSNB P 00320, 00324-00329) from the Eocene (Ypresian) of Forest-lez-Bruxelles, Schaerbeeck, Belgium (Casier 1946, pl. 6 fig. 19a-b). In his review of the London Clay fish fauna, Casier (1966) attributed NHMUK PV P26904 to †E. winkleri as the only skeletal (rather than exclusively dental) material of the species.

We question this attribution of NHMUK PV P26904. There are no obvious features shared uniquely between NHMUK PV P26904 and the type material of $\dagger$ E. winkleri, and we find no clear evidence that they are conspecific beyond similarity in age. Indeed, the type material of $\dagger$ E. winkleri is sufficiently non-diagnostic that we regard identification of these remains at the species level dubious. With respect to generic assignment, more detailed comparisons are possible with the substantially younger type species of the genus, $\dagger E$. delheidi. Similarities with NHMUK PV P26904 are present (e.g. enlarged premaxillary fangs), but these are general features of trichiuroids that provide no evidence for relationships within the group. Pertinently, $\dagger$ E. delheidi bears an anteroventral projection at the tip of the dentary, a feature with limited distribution among trichiurids (e.g. Assurger, Evoxymetopon) but which appears not to be present in NHMUK PV P26904 despite damage to the anterior region of the mandibles. We have no confidence that NHMUK PV P26904 and $\dagger$ E. delheidi form a monophyletic group relative to other trichiuroids, and therefore erect the new taxon $\dagger$ Macroynis casieri to accommodate the London Clay specimen.

\section{Description}

Braincase. The braincase is highly fragmented, presumably due to damage during preservation (Fig. 10). The parasphenoid extends the whole length of the neurocranium but is broken midway along its length, and the posterior part of the parasphenoid and braincase is rotated and displaced laterally. The posteriorly convex basisphenoid that bears a gutter along its midline overlays the posterior margin of the parasphenoid (see .vol files in Beckett et al. 2018). A lateral wing of the parasphenoid contacts the prootic dorsally. Anteriorly, the parasphenoid extends dorsal to the vomer, and the suture between the parasphenoid and vomer is visible in cross section (see .vol files in Beckett et al. 2018). The edentulous vomer is fully half the length of the braincase, tapering to a point well posterior to the lateral ethmoids. Anterolaterally, the vomer widens into broad processes. Hourglass-shaped lateral ethmoids are present on either side of the vomer, with their anterior margins level with the widest part of that bone. Posteriorly, the lateral ethmoids are formed of three struts, one of which contacts the frontal. 
A

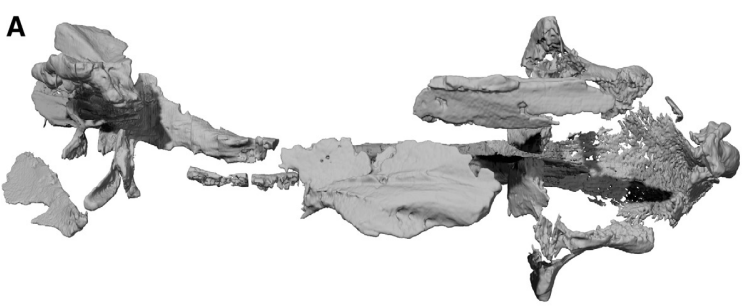

C

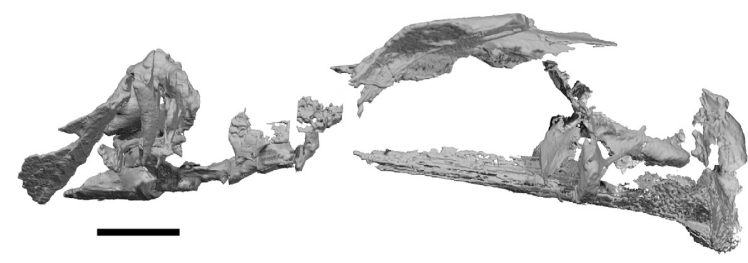

E

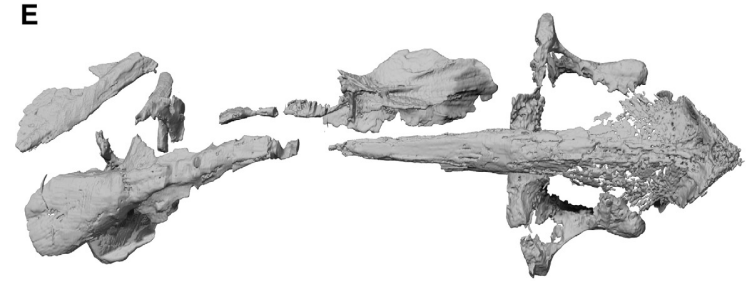

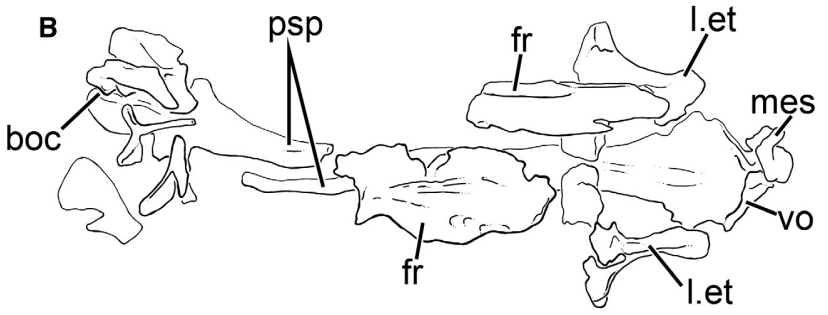

D
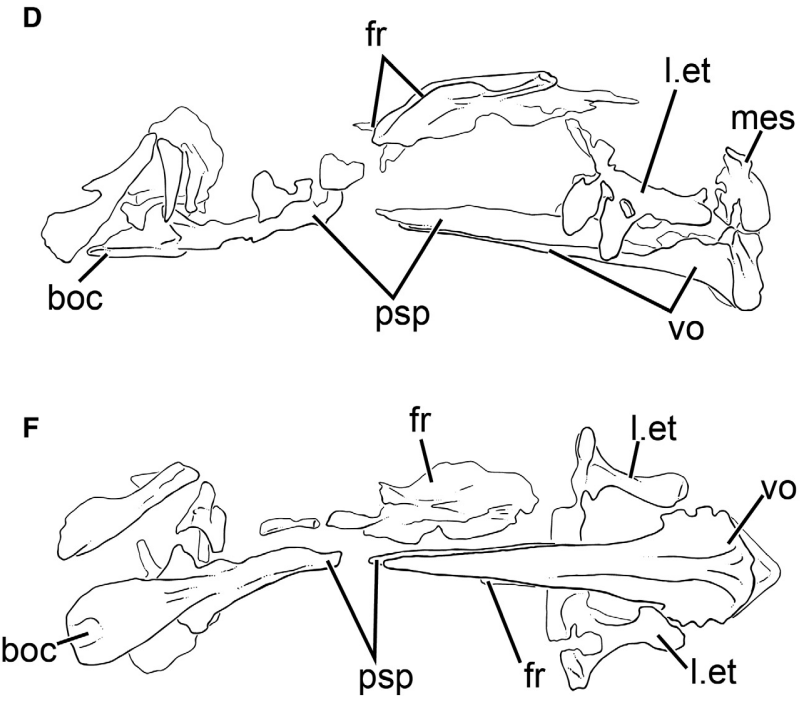

FIG. 1 1. The braincase of $\dagger$ Macroynis casieri (NHMUK PV P26904). A-B, dorsal view; A, rendering; B, drawing. C-D, lateral view; C, rendering; D, drawing. E-F, ventral view; E, rendering; F, drawing. Abbreviations: boc, basioccipital; fr, frontal; l.et, lateral ethmoid; mes, mesethmoid; psp, parasphenoid; vo, vomer. Scale bar represents $10 \mathrm{~mm}$.

Jaws. The upper and lower jaws are preserved on both sides of the specimen (Fig. 11A, B). The upper jaws comprise the maxilla and premaxilla; a supramaxilla is not apparent. The maxilla extends along the length of the ethmoid region of the neurocranium and widens anteriorly to form the premaxillary articular head. At least seven small teeth, of which only the bases are preserved, are borne on the premaxilla. In addition, a single large fang, preserved only on the right side, sits anterior to the smaller teeth. The lower jaw is roughly twice as long as the upper jaw and extends the full length of the neurocranium. The dentary bears a single row of teeth, which decrease in height posteriorly. $\mathrm{Up}$ to four smooth, gently recurved teeth are preserved on each dentary, and smaller cusps at the base of some of these may represent extraosseous replacement teeth (Trapani 2001; see .vol files in Beckett et al. 2018). The posterior portion of the lower jaw is formed by the anguloarticular, which contacts the dentary along a $\mathrm{v}$-shaped margin. A projection of the posterior margin of the anguloarticular forms the articulation point with the head of the quadrate.

Suspensorium. Well-preserved components of the suspensorium include the palatine, endopterygoid, quadrate and symplectic (Fig. 11C, D). In lateral view the palatine consists of an elongate rod dorsally, with a ventral plate-like extension. The ventral expansion is triangular in shape and bears a single row of very small teeth on its lower margin. The anterior margin is concave and articulates with the posterior margin of the maxillary head. In dorsal view, a median palatine shelf extends approximately half the length of the palatine, narrowing anteriorly and widening posteriorly. The shallow, concave endopterygoid is extensively pyritized; no ectopterygoid or metapterygoid is preserved. The preservation of this bone is compromised by extensive pyritization. A fan-shaped quadrate bears a ventral articular condyle. The symplectic is thin and rod-like, the length of which is approximately two-thirds the height of the quadrate. It is housed in a groove on the medial surface of the quadrate.

A fragment of bone on the right side of the fossil probably represents the ventral extension of the hyomandibula, with a small anterior extension forming an articular head.

Hyoid arch. The anterior and posterior ceratohyals and dorsal and ventral hypohyals are preserved on both sides of the skull (Fig. 11E, F). They are largely intact, with minor preparation damage to the ventral margin of the right anterior ceratohyal. The triangular posterior ceratohyal is sutured to the anterior ceratohyal via interleaved bone on its medial surface. The anterior ceratohyal is approximately twice the length of the posterior ceratohyal and is constricted at midlength. The lateral surface is grooved for the afferent hyoidean artery. A perforation (the ceratohyal window) is present at the narrowest point of the anterior ceratohyal and anteriorly there is a robust 
A
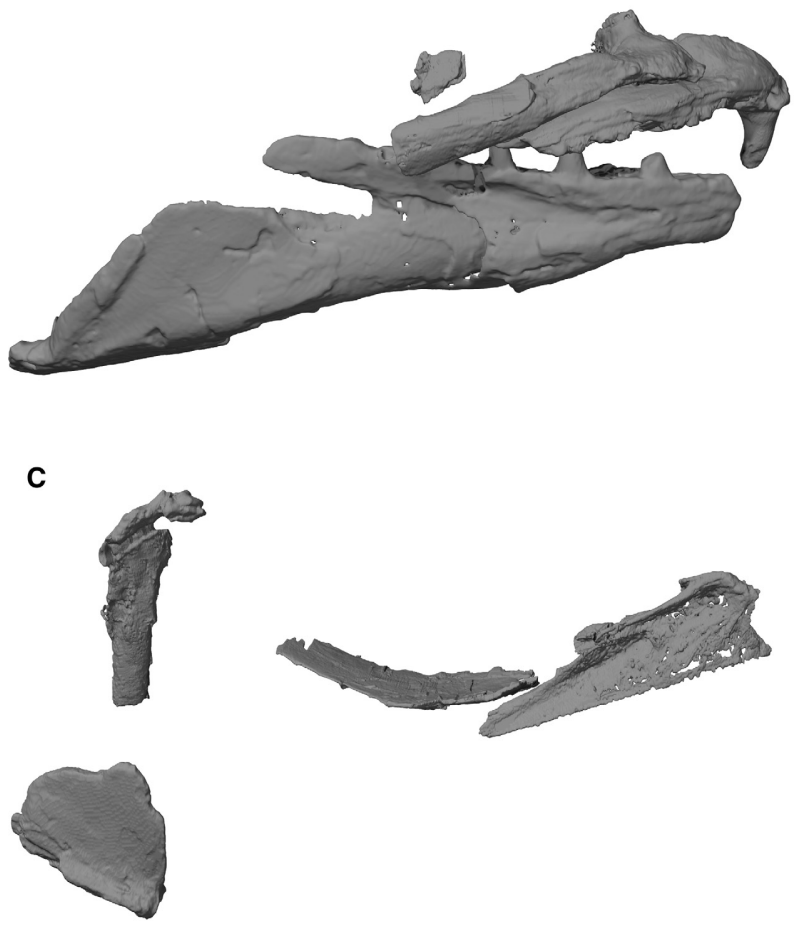

E

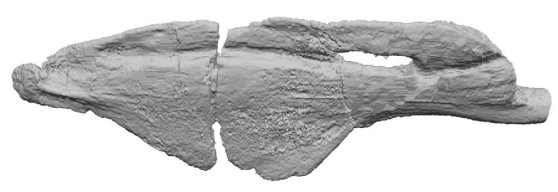

B

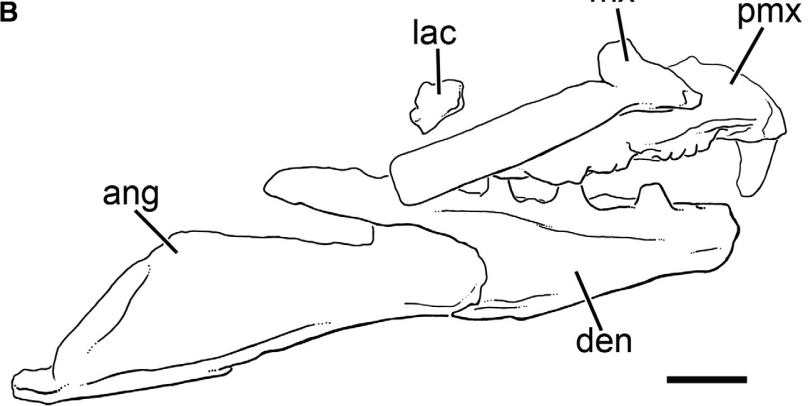

D

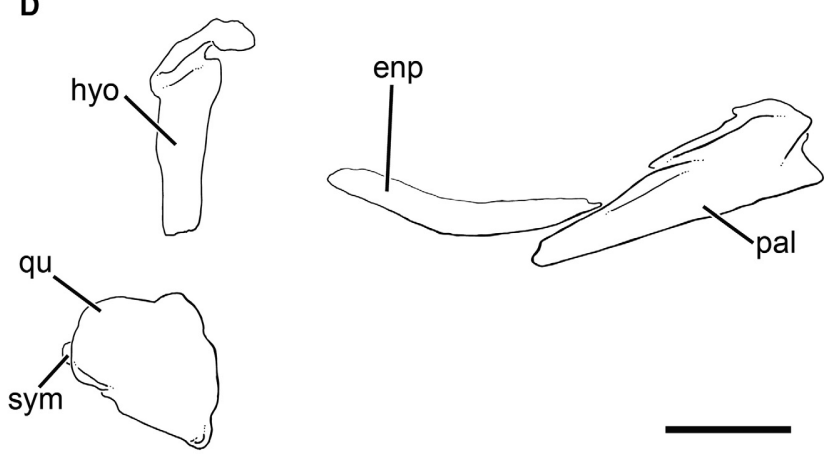

$\mathbf{F}$

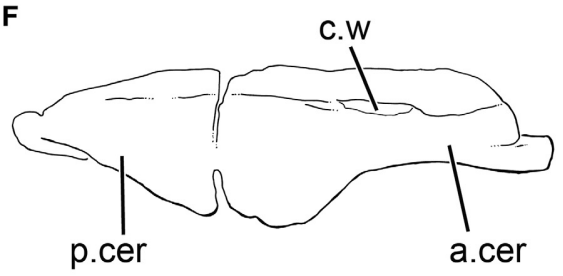

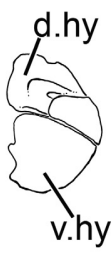

FIG. 11. †Macroynis casieri (NHMUK PV P26904). A-B, jaws in right lateral view; A, rendering; B, drawing. C-D, suspensorium in right lateral view; $\mathrm{C}$, rendering; $\mathrm{D}$, drawing. E-F, hyoid arch in right lateral view; E, rendering; F, drawing. Abbreviations: a.cer, anterior ceratohyal; ang, anguloarticular; c.w, ceratohyal window; den, dentary; d.hy, dorsal hypohyal; enp, endopterygoid; hyo, hyomandibula; lac, lacrimal; mx, maxilla; pal, palatine; p.cer, posterior ceratohyal; pmx, premaxilla; sym, symplectic; qu, quadrate; v.hy, ventral hypohyal. Scale bars represent $10 \mathrm{~mm}$.

tubular extension. The dorsal and ventral components of the trapezoidal hypohyals contact each other at their widest point. The hypohyals are positioned far forward relative to the ceratohyals. The shape of the anterior ceratohyal and position of the hypohyals is mirrored on each side of the specimen, suggesting that the anteriormost portion of the anterior ceratohyal was cartilaginous.

\section{PHYLOGENETIC RESULTS}

Parsimony

A maximum parsimony analysis of morphological data yields 40 most parsimonious trees with a length of 434 steps (consistency index (CI): 0.4097; retention index (RI): 0.7267; rescaled consistency index (RCI):0.2977; Fig. 12). Trichiuroidea (Fig. 12, node A) is supported by five characters, two of which have a CI of 1: ch. 18[1], short ascending process of the premaxilla; ch. 86[1], elongate dorsal articular process of cleithrum. The parsimony analysis recovers 'gempylids' as a grade with respect to monophyletic trichiurids, and clades within the 'gempylid' grade are largely supported by homoplastic characters. Diplospinus + Paradiplospinus is resolved as the immediate sister clade to trichiurids, but with very low nodal support (bootstrap support: 0.56, Bremer decay index: 1). (Diplospinus + Paradiplospinus) + Trichiuridae (Fig. 12, node C) is supported by 13 characters, 3 of which have a 
CI of 1: ch. 4[1], concave posterodorsal margin of the preopercle; ch. 91[1], scale-like external spinous elements of pelvic fin; ch. 113[1], small hypural notch. Trichiurids are recovered as monophyletic, supported by 33 characters, 12 of which have a CI of 1 (Fig. 12, node D; Beckett et al. 2018, S4). Many of the clades within Trichiuridae are also supported by non-homoplastic characters. $\dagger$ Progempylus is resolved as the sister taxon of Ruvettus. Eight characters are optimized as supporting this node, but only two of these can be assessed in $\dagger$ Progempylus: ch. 10 [1], rounded anterior process of subopercle; ch. 68[1], bifurcation of supraoccipital ridge on the supraoccipital. Together †Progempylus and Ruvettus form the sister clade to all other 'gempylid' and trichiurid taxa, with the

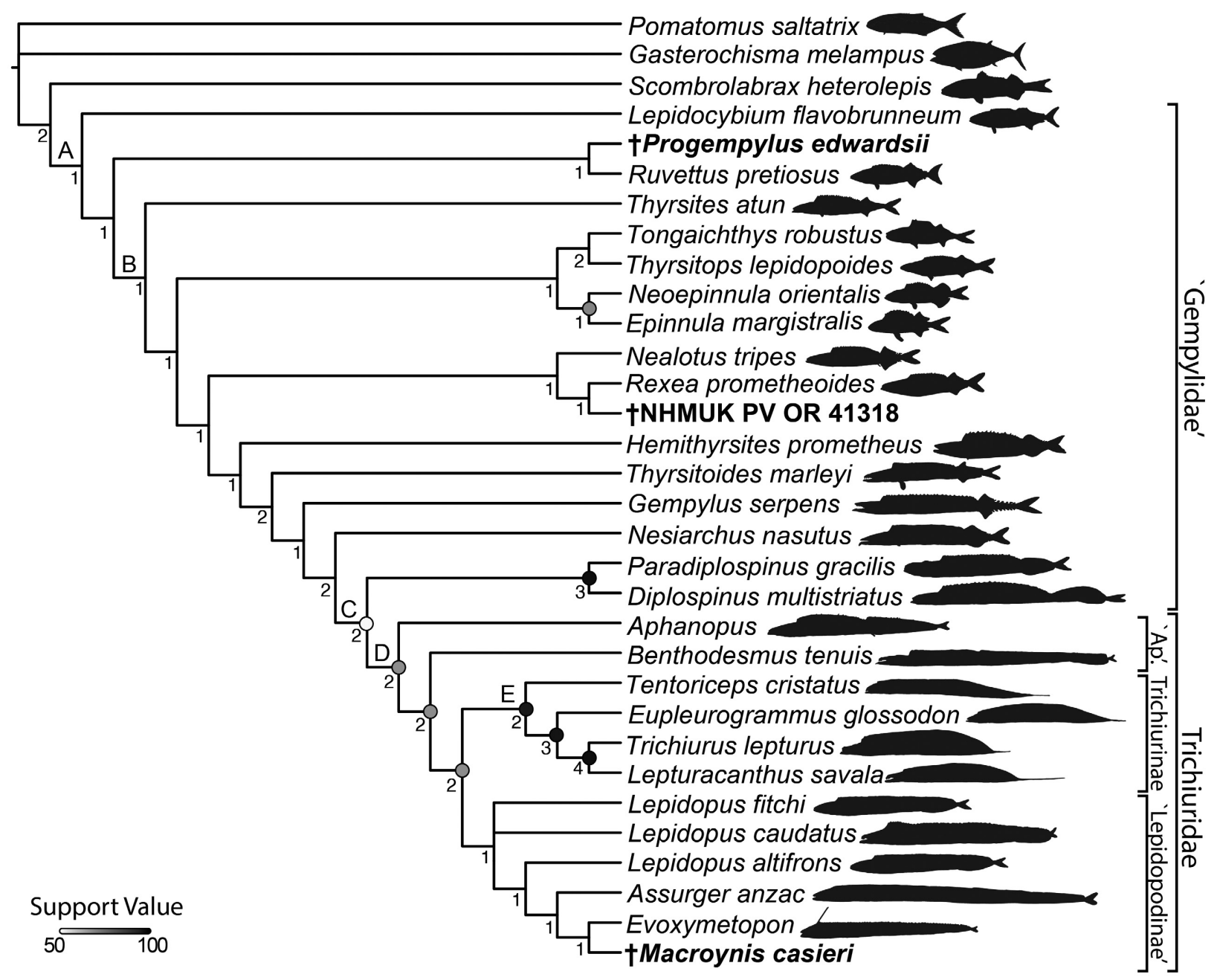

FIG. 12. Relationships of Trichiuroidea based on parsimony analysis of morphological data. Strict consensus of three most parsimonious trees with tree length $=434$ steps. Numbers below nodes represent Bremer decay indices. Circles at nodes indicate bootstrap support values. Fossil taxa in bold. 'Ap.', 'Aphanopodinae'. Trichiurinae as indicated here follows Gago (1998), with the addition of Tentoriceps and Eupleurogrammus, which are always recovered in this clade. Letters at nodes indicate selected character changes with a CI of 1, for remaining characters see Beckett et al. (2018): A, 18[1], short ascending process of the premaxilla; 86[1], elongate dorsal articular process of cleithrum; B, 53[1], two pairs of teeth on the vomer; C, 4[1], concave posterodorsal margin of the preopercle; 91 [1], scale-like external spinous elements of pelvic fin; 113[1], small hypural notch; D, 1[1] posterior margin of opercular series strongly splintered or fimbriate; 58[1] lateral bony tubular extension of supraorbital lateral-line canal to orbital rim; 67[1] pterotic ends well past the posterior margin of the neurocranium; 83[1] posteroventral plate on coracoid present; 96[1], first neural spine distally bifurcate; 101[1], proximal, middle and distal radials in soft dorsal-fin pterygiophores; 117[1], median caudal cartilage present; E, 30[1], anterodorsal corner of ceratohyal pointed; 36[2], articular head of first basibranchial knob-like and bearing dorsolateral processes; 78 [2], anteroventral process of posttemporal separate from poteroventral process; 103[1], foramen at anterioventral corner between the proximal and distal portions of the dorsal-fin proximal radials present; 106[1], anal-fin pterygiophores fused to form a single unit; 108 [1], ultimate centrum not flexed. 
exception of Lepidocybium. Monophyly of trichiuroids minus Lepidocybium (Fig. 12 node B) is supported by four characters, one of which has a CI of 1 and can be coded for $\dagger$ Progempylus: ch. 53[1], two pairs of teeth on the vomer (also seen in Ruvettus, Thyrsites and Neoepinnula).

NHMUK PV OR 41318 is recovered as the sister taxon of Rexea. This placement is supported by a single character: ch. $61[1]$, narrowing of the frontals above the orbit before they widen again above the lateral ethmoids. This is a homoplastic character also present in †Progempylus. Of the characters supporting trichiurids, NHMUK PV OR 41318 can be coded for one: ch. 67[0], pterotic ending before the posterior margin of the neurocranium, a primitive feature excluding it from Trichiuridae.

In a strict consensus, †Macroynis casieri is the sister taxon to Evoxymetopon, within Trichiuridae. This placement is supported by two characters, both reversals occurring elsewhere in the tree but only co-occurring in these two genera: ch. 23[0], anterior tooth in line with the remaining dentary teeth; ch. 33[0], presence of a ceratohyal window. All characters coded for †Macroynis casieri show homoplasy.

\section{Bayesian morphology}

As in the parsimony analysis, 'gempylids' are recovered as a grade with respect to a monopyletic Trichiuridae (Fig. 12). In the maximum clade credibility tree (Fig. 12A), nodes within the 'gempylid' grade are poorly supported, with all relationships of 'gempylids' deeper in the tree than Nesiarchus collapsing to 'gempylid' polytomy in the majority-rule tree (Fig. 12B). In the maximum clade credibility tree, †Progempylus edwardsi and NHMUK PV OR 41318 are recovered as sister taxa in a clade with Neoepinnula + Epinnula and †Macroynis casieri is recovered as sister taxon to the grade that includes Thyrsitoides, Gempylus, Nesiarchus, Diplospinus + Paradiplospinus and Trichiuridae (Fig. 12A). However, in the majority-rule tree all fossil taxa lie within the 'gempylid' polytomy. Diplospinus + Paradiplospinus represent the immediate 'gempylid' sister group to the monophyletic trichiurids with a support value of 0.70 . The trichiurid clade has a posterior probability of 0.88 .

\section{Bayesian combined analysis}

In agreement with the parsimony and Bayesian morphology only analyses, 'gempylids' are recovered as a grade with respect to trichiurids in the maximum clade credibility tree, albeit with very poor support (Fig. 13A). Trichiurids are resolved as a clade with a posterior probability of 0.87. In the majority-rule consensus tree (Fig. 13B), 'gempylids' form a polytomy at the base of the tree and Trichiuridae are monophyletic, the latter supported by a Bayesian posterior probability of 0.87 . Three pairs of 'gempylid'-grade taxa form clades with variable support: Thyrsitoides + Gempylus (0.73), Neoepinnula + Epinnula (0.56), and Tongaichthys + Thyrsitops (0.89). Diplospinus and Paradiplospinus form a clade with Nesiarchus as its sister taxon; the monophyly of this group is supported with a posterior probability of 0.82 . In the maximum clade credibility tree $\dagger$ Progempylus edwardsi and $†$ Macroynis casieri form a clade, with NHMUK PV OR 41318 falling as the sister taxon of Rexea + (Hemithyrsites + Nealotus). However, all of the fossil taxa are placed within the basal polytomy in the majority-rule consensus tree.

Removing fossils from the analysis recovers a tree (Beckett et al. 2018, S5) with three principal clades, all of which have posterior probabilities above 0.8 . Two of these clades contain 'gempylids', and branch as two successively more remote outgroups to a monophyletic Trichiuridae, the latter supported by a posterior probability of 1 . The most deeply diverging clade contains Lepidocybium, Ruvettus, Neoepinnula, Epinnula, Tongaichthys and Thyrsitops. The remaining 'gempylids' form a clade that falls as sister to the trichiurids, and this sister relationship has a posterior probability of 1 . Trichiurid monophyly is also strongly supported, with a posterior probability of 1 .

\section{DISCUSSION}

\section{Relationships within Trichiuroidea}

Across all analyses, our results consistently recover a monophyletic Trichiuridae nested within poorly supported grade of 'gempylids'. This result is in line with previous morphological (Tucker 1956; Johnson 1986; Potthoff et al. 1986; Carpenter et al. 1995; Gago 1997) and molecular (Orrell et al. 2006; Betancur-R et al. 2013, 2017; Miya et al. 2013; Near et al. 2013) analyses. Within this, relationships among 'gempylids' are highly variable, but Lepidocybium and Ruvettus are consistently recovered as the earliest diverging extant taxa. While trichiurids are consistently monophyletic, some relationships within the clade vary compared to previous hypotheses.

In our analyses of morphological characters (under both parsimony and Bayesian frameworks; Figs 12, 13), relationships among 'gempylids' agree broadly (and unsurprisingly) with those reported by Russo (1983), a major source of our characters. Lepidocybium and Ruvettus are recovered in both morphological analyses (Figs 12, 13) as successively branching sister taxa to the remaining ingroup. This deep split between Lepidocybium and all remaining trichiuroids was argued by Johnson (1986), but is not routinely supported by molecular analyses (Orrell 
A

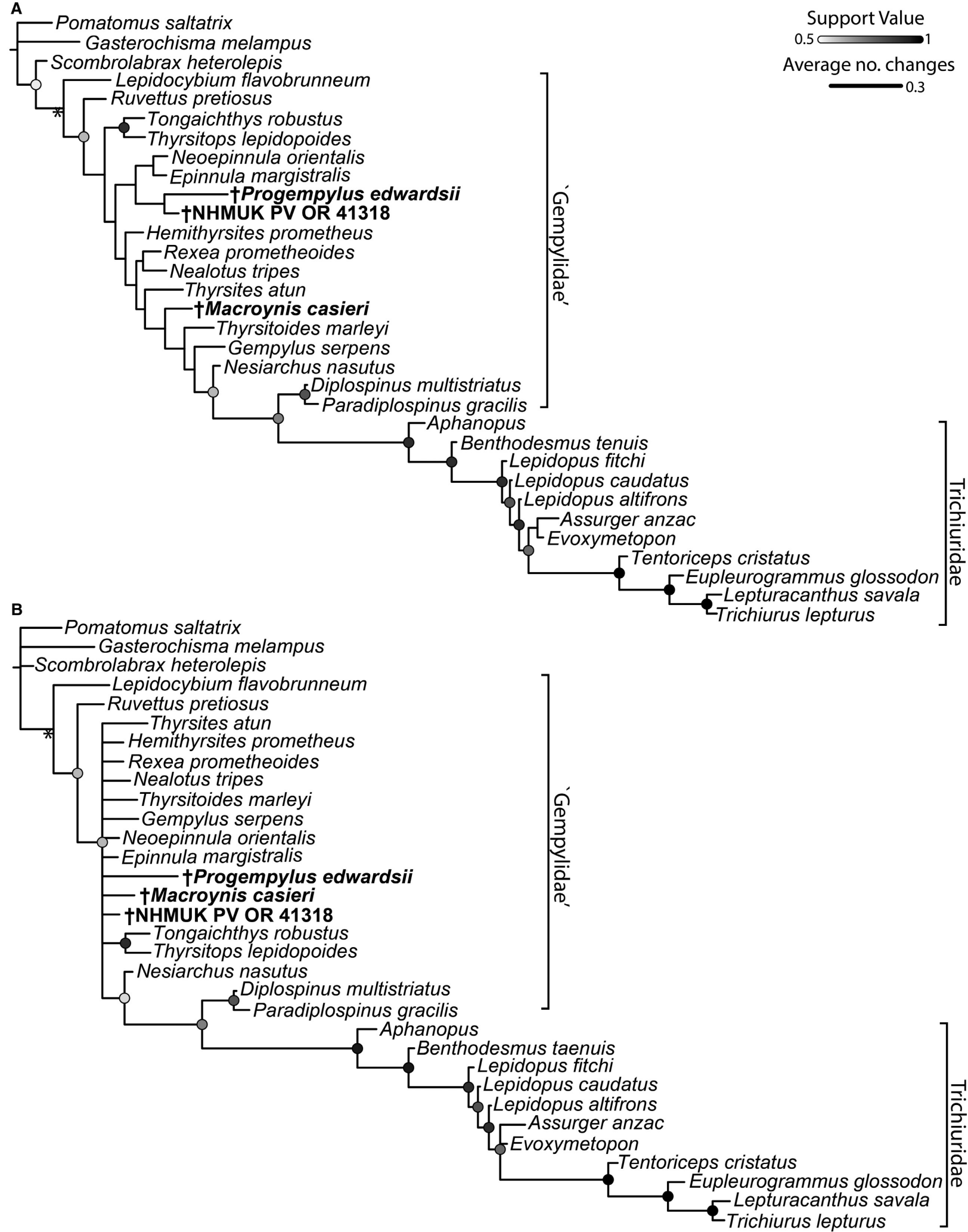

FIG. 13. Relationships of Trichiuroidea based on Bayesian analysis of the morphological dataset: A, the maximum clade credibility tree; B, the majority-rule consensus tree. Circles at nodes indicate Bayesian posterior probabilities above 0.5. Starred nodes are enforced. Fossil taxa in bold. 
et al. 2006; Miya et al. 2013) or our combined analysis (Fig. 14). Paradiplospinus + Diplospinus is recovered in all analyses as the most nested 'gempylid' clade (Russo 1983) and the sister clade to trichiurids in the morphology analyses (Gago 1997, 1998). Diplospinus has historically been closely aligned with trichiurids, and was initially placed within the group (Tucker 1956) before its subsequent removal (Parin \& Becker 1972). The elongate body plan of Diplospinus resembles that of trichiurids, lending support to a close relationship. However, Paradiplospinus and Diplospinus are rarely included in molecular analyses, so molecular support for this hypothesis is sparse (Orrell et al. 2006; Miya et al. 2013; Near et al. 2013; Betancur-R et al. 2017). Addition of molecular data to our analyses results in a different pattern of relationships among 'gempylids'. Rather than comprising numerous successive outgroups to trichiurids, 'gempylids' remain a grade but fall within a more restricted set of clades. However, the monophyly and mutual relationships of these clades are poorly supported in analyses that include fossil taxa. Removal of fossils from the combined dataset results in a well-supported pair of 'gempylid' clades (Beckett et al. 2018, S5), containing similar constituent taxa to those recovered in previous molecular analyses (Orrell et al. 2006; Miya et al. 2013), but showing different internal relationships. Other published molecular analyses including multiple 'gempylid' taxa likewise show little agreement between inferred relationships either within the assemblage or to trichiurids (Orrell et al. 2006; BetancurR et al. 2013, 2017; Miya et al. 2013; Near et al. 2013). Satisfactory resolution of 'gempylid' interrelationships remains elusive, and we anticipate that molecular studies targeting additional lineages and increased number of loci might provide increased clarity (see Harrington et al. 2016 for a similar case).

In contrast to the ambiguity concerning 'gempylid' relationships, we find good support for Trichiuridae (cf. Gago 1998; Betancur-R et al. 2013, 2017; Miya et al. 2013; Near et al. 2013) and broadly consistent patterns of relationships within the group between analyses. Our results provide a test of the division of trichiurids into three 'tribes' by Tucker (1956): Aphanopodinae (Diplospinus, Aphanopus and Benthodesmus), Lepidopodinae (Assurger, Tentoriceps, Lepidopus, Evoxymetopon and Eupleurogrammus), and Trichiurinae (Trichiurus and Lepturacanthus). Of these historically recognized 'tribes' sensu Tucker (1956) only the Trichiurinae are consistently recovered as monophyletic. All of our analyses resolve Lepidopodinae sensu Tucker (1956) as paraphyletic with respect to his Trichiurinae. In particular, we find that Eupleurogrammus and Tentoriceps are always successive sister groups of trichiurines. Gago (1998) recovered a similar arrangement and moved Eupleurogrammus to the Trichiurinae, to which we also add Tentoriceps. This group of four genera is a consistent feature across our analyses. The remaining 'lepidopodines' fall as a grade in Bayesian analyses (Figs 13-14), in agreement with Gago (1997, 1998). Tucker's (1956) evolutionary tree of trichiurids implies that Aphanopodinae are a grade, with Diplospinus being the deepest branch (Tucker 1956, fig. 23). Parin \& Becker (1972) removed Diplospinus to the 'gempylids', a result supported by Gago $(1997,1998)$ and our analyses. The core 'aphanopodines' are paraphyletic in our morphological analyses as well as those of Gago (1998), but our combined analysis supports monophyly of Aphanopus + Benthodesmus, a result also recovered in previous molecular analyses (Miya et al. 2013; Betancur-R et al. 2017). In sum, we consistently recover three trichiurid assemblages across our analyses: Aphanopus and Benthodesmus at the base of Trichiuridae; 'Lepidopodinae', either as the monophyletic sister to trichiurines (in the parsimony analysis) or a paraphyletic grade with respect to trichiurines (in the Bayesian analyses); a monophyletic Trichiurinae (Fig. 12, node E), which falls as the most nested trichiurid clade in the Bayesian analyses. Further morphological and molecular studies should target the relationships of the 'Lepidopodinae', which are particularly unstable.

\section{Placement of London Clay fossils within Trichiuroidea}

$\dagger$ Progempylus was aligned with 'gempylids' and trichiurids by Casier (1966), who noted its similarity to Gempylus. Monsch (2000, 2005) also placed †Progempylus with 'gempylids' because of its recurved conical teeth. In his unpublished analysis, Monsch (2000, fig. 8.1) recovered $\dagger$ Progempylus in a basal polytomy uniting several fossil taxa with Trichiuroidea and a clade containing scombrids and xiphioids. In our analyses, $\dagger$ Progempylus is consistently recovered as a 'gempylid'. In the parsimony analysis, $\uparrow$ Progempylus is recovered near the base of the tree in a clade with Ruvettus (supported by: ch. 10[1], rounded anterior process of subopercle; ch. 66[1], bifurcation of supraoccipital ridge on the supraoccipital). †Progempylus is nested within 'gempylids' in both Bayesian analyses, with no particular relationship to Ruvettus. In the morphology analysis, it falls in a clade with Epinnula,

FIG. 14. Relationships of Trichiuroidea based on the Bayesian analysis of the combined morphology and molecular dataset (mitochondrial data from Miya et al. 2013): A, the maximum clade credibility tree; B, the majority-rule consensus tree. Circles at nodes indicate Bayesian posterior probabilities above 0.5. Starred nodes are enforced. Fossil taxa in bold. 
A

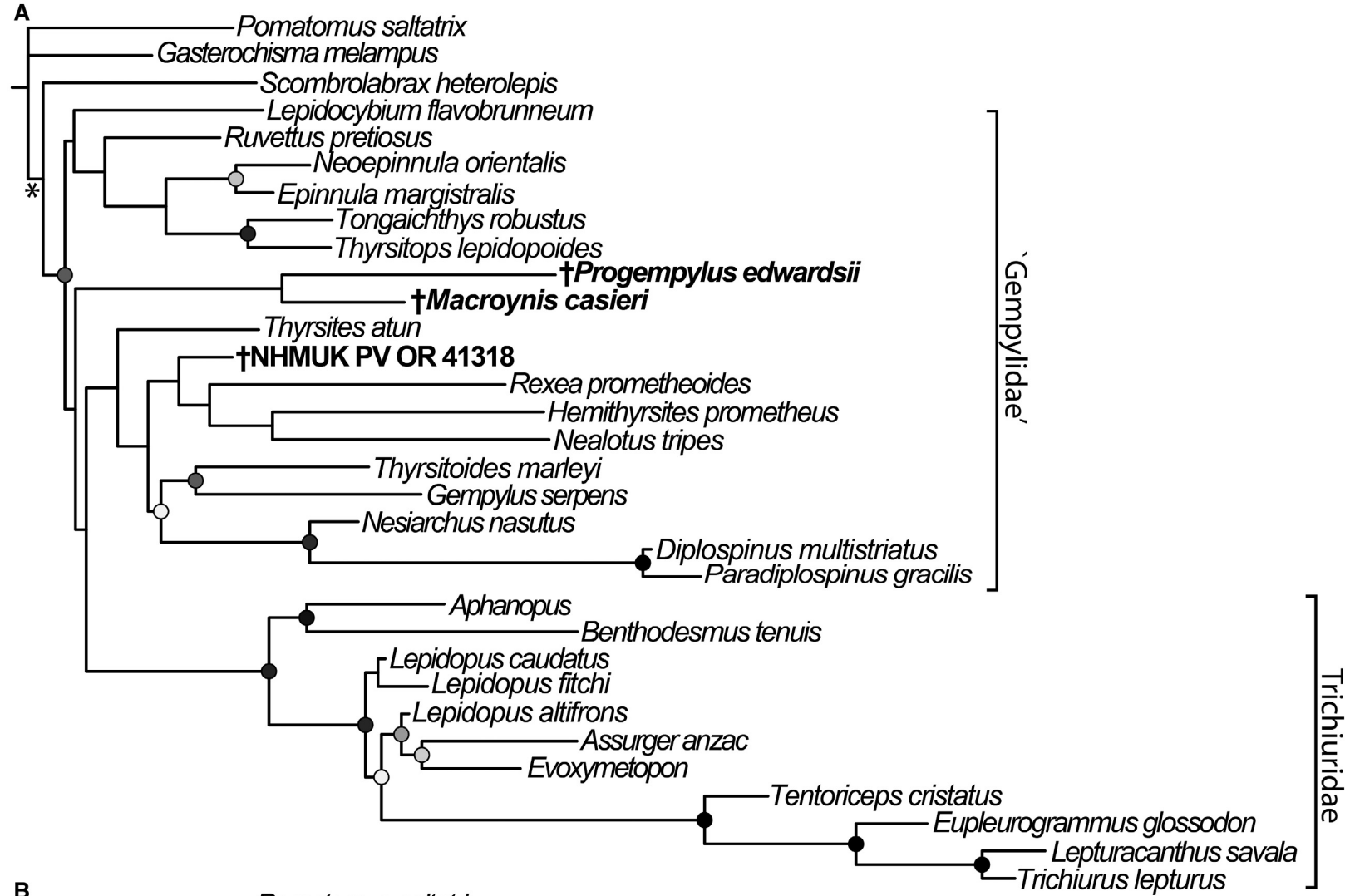

B

Pomatomus saltatrix

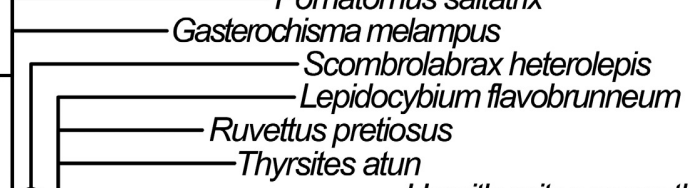

Scombrolabrax heterolepis

Thyrsites atun

Hemithyrsites prometheus

Realotus tripes

Macroynis casieri

tProgempylus edwardsii

* + NHMUK PV OR 41318

Neoepinnula orientalis

Epinnula margistralis

Tongaichthys robustus

Thyrsitops lepidopoides
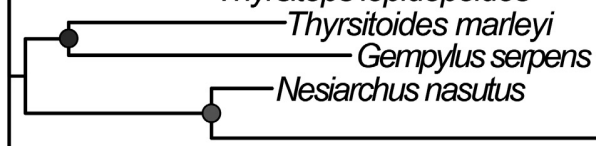

Nesiarchus nasutus

Diplospinus multistriatus

Paradiplospinus gracilis

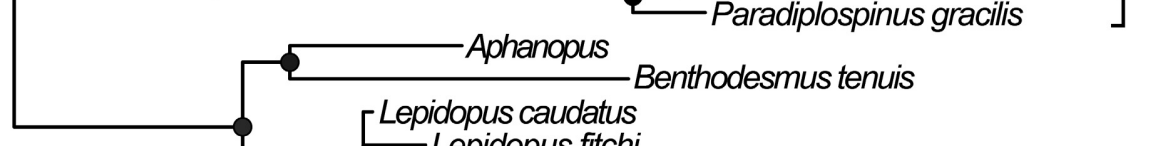

ด́

$\frac{1}{3}$

Lepidopus fitchi

5 Lepidopus altifrons

E_ Assurgeranzac

Evoxymetopon

Eupleurogrammus glossodon 
Neoepinnula and NHMUK PV OR 41318. Conversely, in the combined analysis maximum clade credibility tree $\dagger$ Progempylus is recovered with $\dagger$ Macroynis, albeit with very weak support $(\mathrm{BPP}<0.5)$. We consider $\dagger$ Progempylus to be a deeply diverging trichiuroid but can propose no more precise assignment at present.

NHMUK PV OR 41318 has been interpreted as a trichiurid based on association with $\dagger$ Macroynis (Casier 1966, p. 249, fig. 56). Despite this, Casier (1966, p. 249, fig. 56) described the morphology of this braincase as intermediate between scombrids (e.g. $\dagger$ Scombrinus) and trichiurids (e.g. Lepidopus), and Monsch (2005) assigned it to 'Gempylidae' incertae sedis. In our parsimony analysis (Fig. 12) NHMUK PV OR 41318 is recovered as the sister taxon of Rexea (supported by a single homoplastic character: ch. 61[1], narrowing of frontals above the orbit). NHMUK PV OR 41318 is excluded from the trichiurid crown by character 67[0], as it displays the primitive state of the pterotic ending before the posterior margin of the neurocranium (ch. 67[1]: the pterotic extends beyond the posterior margin of the braincase in trichiurids). The braincase shows more general similarities with Rexea, including a 'box-like' lateral profile and extension of the supraoccipital crest over the posterior margin of the exoccipitals. NHMUK PV OR 41318 is recovered as sister to $\dagger$ Progempylus in our Bayesian morphology analysis (Fig. 13A), and as sister to a clade comprising Rexea and other 'gempylids' in our combined analysis (Fig. 14A), although collapses into the 'gempylid' polytomy in the majority-rule consensus tree of both analyses (Figs 13B, 14B). The placement of NHMUK PV OR 41318 outside the trichiurid clade in phylogenetic analyses supports its historical placement in the paraphyletic 'Gempylidae'. We consider NHMUK PV OR 41318 Trichiuroidea incertae sedis, but are confident it can be excluded from Trichiuridae.

The specimen renamed here as $†$ Macroynis has historically been considered to be a trichiurid (Leriche 1910; Arambourg \& Signeux 1952; Casier 1966; Monsch 2000, 2005) due to its straight serial teeth. Casier (1966) and Monsch (2005) suggested a series of characters tying $\dagger$ Macroynis to 'gempylids' and trichiurids more generally: premaxillary fangs (seen elsewhere in Scombrolabrax but not scombrids), an elongated skull (typically associated with an elongate body), and a tightly bound maxilla and premaxilla (seen elsewhere in scombrids but not Scombrolabrax). Despite this, no formal phylogenetic analyses have been conducted that incorporate either this specimen or †Eutrichiurides (with which it was previously associated) more generally. In our parsimony analysis, $\dagger$ Macroynis is resolved as highly nested within Trichiuridae as the sister taxon to Evoxymetopon (based on the reversal of two highly homoplastic characters). However, this relationship is not upheld in our Bayesian analyses where it is recovered as a 'gempylid' (Bayesian morphology: Fig. 13A; Bayesian combined: Fig. 14A). While this contradicts previous assessments of its placement, this is perhaps unsurprising given the limited character information that can be obtained for $\uparrow$ Macroynis. The highly fragmented braincase of $\dagger$ Macroynis results in a large number of uncodeable characters in a morphological matrix that largely targets the braincase, suggesting that its nested position in the parsimony analysis may be due to a 'path of least resistance' rather than any meaningful support. However, visual inspection of $\dagger$ Macroynis indicates similar jaw proportions to extant trichiurids such as Aphanopus and Evoxymetopon, with the upper jaw extending notably anterior to the braincase and the articulation of the lower jaw behind the midpoint of the orbit. A similar morphology is seen in some elongate 'gempylids' (e.g. Nesiarchus, Diplospinus, Paradiplospinus), in particular those that have previously been either included in (Diplospinus: Tucker 1956), or closely associated with, Trichiuridae in the past (Carpenter et al. 1995; Gago 1998). †Macroynis can be confidently placed in Trichiuroidea, but is of uncertain placement within this group. The morphological analysis suggests a close association with those species with an elongate body plan, either trichiurids or a subset of 'gempylids' sometimes recovered as closely related to trichiurids. However, there is greater uncertainty associated with this placement due to the ambiguities in the relationships of 'gempylids'. As with †Progempylus, we consider $\uparrow$ Macroynis to be incertae sedis within Trichiuroidea, but unlike that genus we cannot exclude the possibility of placement within Trichiuridae.

An overview of the fossil record of Trichiuroidea, with comments on the placement of key fossil taxa

Fossil trichiuroids can broadly be categorized in two groups: firstly, those assigned to extant genera; and secondly, those representing extinct lineages. Extant trichiuroid genera with a fossil record include Lepidopus $(\dagger L$. brevicauda from the Oligocene of Switzerland, $\dagger L$. hungaricus from the Oligocene of Hungary and $\dagger L$. angustus from the Oligocene of the Caucasus: Daniltshenko 1980; Dzhafarova 1988; $\dagger L$. lednevi and $\dagger L$. lateralis from the Miocene of Azerbaijan, $\dagger L$. albyi from the Miocene of Italy and $\dagger L$. proargenteus from the Miocene of Algeria: Arambourg 1927); Thrysitoides ( $\dagger$ T. zarathoustrae from the Eocene of Iran: Arambourg 1943); Epinnula ( $\dagger$ E. cancellata from the Eocene of Iran: Arambourg 1967); and Hemithyrsites ( $\dagger$ H. armatus from the Miocene of Italy: Sauvage 1873; here we follow Monsch \& Bannikov 2012 in synonymizing Hemithyrsites and Promethichthys).

In addition to the taxa described in this paper, trichiuroids assigned to fossil genera include: †Argestichthys 
from the earliest Eocene (Ypresian) of Turkmenistan (Prokofiev 2002); †Abadzekhia from the early-late Oligocene (Rupelian-Chattian) of the Caucasus (Bannikov 2005) and Germany (Bannikov 2010); †Chelifichthys from the late Miocene (Messinian) of Algeria (Carnevale 2006); $\dagger$ Anenchelum from the middle Eocene to early Miocene of Europe; $\dagger$ Eutrichiurides from the early Oligocene (Rupelian) of Belgium (we refer to skeletal remains only; isolated teeth attributed to the genus are more widespread but their attributions are questionable) and $\dagger$ Musculopedunculus from the early Oligocene (Rupelian) of Germany (Parin \& Astakhov 2007). Although several of these genera are represented by near-complete fossils, lateral compression and associated concealment of the braincase and gill arches means that relatively few morphological characters can be scored. We comment below on possible placements of these genera based on previously published descriptions and character optimizations (Beckett et al. 2018, S4) from our phylogenetic analyses. Several as-yet undescribed Eocene trichiuroids have been figured in the literature (Bonde et al. 2008; Zorzin et al. 2011; Giusberti et al. 2014), but published photographs reveal too little detail to meaningfully comment on their placements.

$\dagger$ Argestichthys is the oldest described trichiuroid body fossil (Prokofiev 2002). Prokofiev noted a series of primitive features shared by $\dagger$ Argestichthys and gempylids, and argued for a similar insertion pattern of anal-fin pterygiophores in the genus and Ruvettus (questioned by Monsch \& Bannikov 2012, p. 264). However, Prokofiev later suggested that $\uparrow$ Argestichthys shows 'proximity to the generalised ancestor of Trichiuridae' (Prokofiev 2002, p. 233), implying a position on the trichiurid stem. Monsch \& Bannikov (2012) classified $\dagger$ Argestichthys as Trichiuroidea incertae sedis, but tentatively placed it as a stem trichiurid in their composite tree. A combination of premaxillary fangs and a short ascending process of the premaxilla are consistent with a trichiuroid placement of $\dagger$ Argestichthys. Both features are present in other lineages of Pelagia (e.g. Scombridae, Scombrolabrax) but not in conjunction. However, the postmaxillary process is not well developed (ch. 21[0]), unlike the condition in trichiuroids but similar to that of outgroups. The reduced supraoccipital crest (ch. 63[1]) is found in 'gempylids' excluding Lepidocybium and Ruvettus, however the distribution among trichiurids is more complex, with a reversal in Assurger, Eupleurogrammus, Evoxymetopon and Lepidopus. Spine-like external elements of the pelvic-fin spine restrict $\dagger$ Argestichthys to outside Trichiuridae $+($ Diplospinus + Paradiplospinus $)$ ) (ch. 91[0]; they are scale-like in Trichiuridae + (Diplospinus + Paradiplospi$n u s)$ ). This combination of primitive characters suggest that $\dagger$ Argestichthys is a very deeply diverging member of crown Trichiuroidea, or possibly even on the trichiuroid stem.

$\dagger$ Abadzekhia has been assigned to 'Gempylidae' (Bannikov 1985; Bannikov \& Fedotov 1989) close to
Tongaichthys, Thyrsitops, Ruvettus and Lepidocybium (Bannikov 2005). It can be placed within Trichiuroidea on the basis of the short ascending process of the premaxilla (ch. 18[0]; also seen in scombrids), and a low but distinct postmaxillary process (Bannikov 2017) (ch. 21[0]; a welldeveloped process is a synapomorphy of Trichiuroidea). Within the trichiuroids, †Abadzekhia can be further constrained outside of Trichiuridae + (Diplospinus + Paradiplospinus)) based on the absence of two nonhomoplastic characters which support this clade: two radials are reported in the soft dorsal fin pterygiophores by Bannikov (2005) (ch. 101[0]; three are seen in Trichiuridae although given the size of the additional radial (Johnson 1986, ch. 30) it is difficult to distinguish genuine absence from taphonomic loss in fossils) and the external elements of the pelvic-fin are spine-like (ch. 91 [0] they are scale like in Trichiuridae + (Diplospinus + Paradiplospinus)).

$\dagger$ Chelifichthys was assigned to 'Gempylidae' by Carnevale (2006), and described as closely related to Nealotus, Hemithyrsites, Rexea and Rexichthys. It cannot be evaluated for any of the synapomorphies that support Trichiuroidea, however it has a moderately sized supraoccipital crest (ch. 63[1]; found in 'gempylids' excluding Lepidocybium and Ruvettus; trichiurids are characterized by further reduction of the crest, ch. 63[2]). †Chelifichthys also has a preopercle that is widest at the angle of the bone (ch. 5[0]), which excludes it from the clade comprising Nesiarchus $+(($ Diplospinus + Paradiplospinus $)+$ Trichiuridae). $†$ Chelifichthys shows a weakly splintered preopercle (ch. 1[0]) and two radials in the soft dorsal fin pterygiophores (ch. 101[0]; Carnevale 2006, fig. 4C; see caveats above for fossils in discussion of $\dagger$ Abadzekhia), two primitive features that show derived states in Trichiuridae. Limitations in preserved anatomy preclude precise placement within Trichiuroidea but $\dagger$ Chelifichthys can be placed within the 'gempylid'-grade in a position more closely related to trichiurids than Lepidocybium and Ruvettus, but outside of the clade comprising Nesiarchus, Diplospinus, Paradiplospinus and Trichiuridae.

The oldest body fossil associated with trichiurids is a specimen similar to $†$ Anenchelum from the Ypresian of Monte Solane, Italy (Zorzin et al. 2011) that shows the elongate body plan associated with trichiurids. $\dagger$ Anenchelum itself is known from a number of sites, with nominal species ranging in age from Eocene to Miocene. The taxonomic history of $\uparrow$ Anenchelum is complicated, largely due to reclassification of species between this genus and the extant Lepidopus. Woodward (1901) synonomized these two genera, but Bannikov \& Parin (1995) upheld the validity of $\dagger$ Anenchelum and recognized the following species: the type $\dagger$ Anenchelum glarisianum (Blainville 1818) from several deposits of Oligocene age; $\dagger$ Anenchelum eocaenicus (Daniltshenko 1962) from the middle Eocene of 
Georgia; †Anenchelum paucivertebrale from the middle Eocene of the Northern Caucasus (Bannikov \& Parin 1995); †Anenchelum angustum (Daniltshenko, 1980) from the early Oligocene of the Caucasus and $\uparrow$ Anenchelum lednevi (Menner 1949) from the early Miocene (upper Maikopian) of Caucasus. These authors also suggest that the Oligocene Lepidopus hungaricus and L. brevicauda might belong to †Anenchelum. Many of the diagnostic features of $\dagger$ Anenchelum are admittedly generalized trichiuirid characters (Bannikov \& Parin 1995, p. 186).

Most species of $\uparrow$ Anenchelum are poorly known, or descriptions are largely meristic counts with few details of the skull, so here we restrict consideration to the most completely described species: $†$. paucivertebrale and $\dagger$ A. glarisianum (Bannikov \& Parin 1995; Gregorova 2010). Bannikov \& Parin (1995) considered $\dagger$ A. paucivertebrale to be the ancestor of 'Aphanopodinae' and 'Lepidopodinae', effectively suggesting a placement close to the crown trichiurid node. $\dagger$. paucivertebrale has premaxillary fangs and a short ascending process of the premaxilla, which occur together in trichiuroids. As noted by Bannikov \& Parin (1995) it shows a differentiated soft and spinous portion of the dorsal fin (ch. 99[0]; a primitive feature retained by 'gempylids' + Aphanopus and Benthodesmus). The preopercle is widest opposite the dorsal arm (ch. 5[1]; observed in trichiurids, Diplospinus + Paradiplospinus, Nesiarchus). No epineurals are observed in the material (Bannikov \& Parin 1995; ch. 98[2]; the absence of epineurals is a trichiurid synapomorphy). The caudal complex is well developed (ch. 107[0]; seen in 'gempylids', 'Aphanopodinae', and 'Lepidopodinae'). $\dagger$. paucivertebrale also has a slightly lower vertebral count (ch. 76: Bannikov \& Parin 1995) than extant Trichiuridae (typically around 100: Nakamura \& Parin 1993), but higher than even the most elongated 'gempylids' (Paradiplospinus: 60-64). Collectively, these features suggest a position on the trichiurid stem. $\uparrow$ A. glarisianum has a more typical vertebral count for a trichiurid (110; ch. 95[2]) and shows three derived features of trichiurids in its opercular series: ch. 1[1], the opercular series is strongly fimbriate; ch. $6[0]$, the posterior opercular spine is absent; and ch. 10[1], the anterior process of the subopercle is rounded. It can also be excluded from the Trichiurinae + Lepidopodinae based on the presence of a notch between the soft and spinous portions of the dorsal fin (ch. 99[0]). While it is clear that the affinities of $\uparrow$ Anenchelum lie with Trichiuridae, it is less clear whether its constituent species form a clade given the meristic variation observed among them.

$\dagger$ Musculopedunculus was previously assigned to its own monotypical family, Musculopedunculidae, by Parin \& Astakhov (2007), who suggested affinities with Lepidopus and $\dagger$ Anenchelum. Within the context of the synapomorphy scheme generated by the present study, the genus can be constrained within Trichiuroidea based on the short ascending process of the premaxilla (ch. 18[0]). An elongate bodyform with a high number of vertebrae (ch. 95[2]) and the absence of attached epineurals and epicentrals in the caudal region (ch. 98[2]) place it in Trichiuridae. The plesiomorphic presence of a flexed ultimate centrum forming a urostyle (ch. 108[0]) and a well-developed caudal fin in $†$ Musculopedunculus exclude the genus from Trichiurinae. Additionally, $†$ Musculopedunculus shows no division between the spinous and soft parts of the dorsal fin (ch. 99[1]), a derived feature seen in all trichiurids apart from Aphanopus and Benthodesmus. A well-developed supraoccipital crest (ch. 63 [0]) suggests placement within the 'Lepidopodinae'. $\dagger$ Musculopedunculus is therefore considered to be a crown trichiurid.

$\dagger$ Eutrichiurides delheidi, from the Boom Clay of Belgium, is the type species of the genus, and is represented by a premaxilla, dentary and teeth. The premaxilla shows a fang, seen in Scombrolabrax and trichiuroids (Johnson 1986), but no other characters exclusive to trichiuroids are apparent. Within trichiuroids, the dentary shows an anteroventral projection at the tip of the jaws as seen in the trichiurids Assurger and Evoxymetopon. Based on this admittedly scant evidence, we consider $†$ Eutrichiurides delheidi Trichiuroidea incertae sedis.

These body fossils show that probable 'gempylids' appear in the geological record (†Argestichthys) before anatomically primitive trichiurids (†Anenchelum, including the undescribed specimen). This pattern is consistent with the sequence of evolutionary origins implied by past morphological and molecular analyses that reconstruct 'gempylids' as a grade (Collette et al. 1984; Johnson 1986; Potthoff et al. 1986; Carpenter et al. 1995; Orrell et al. 2006; Miya et al. 2013; Near et al. 2013), as well as with our own results. Formal assessment of trichiuroid body fossils requires a molecular dataset with broad sampling across the trichiuroids, in addition to an improved morphological dataset, with particular focus on characters not pertaining to the braincase. Lacking new specimens, future work on placing fossil trichiuroid taxa should target well-preserved or geologically older specimens, especially those that are as yet undescribed (e.g. Zorzin et al. 2011).

\section{CONCLUSIONS}

Computed tomography has revealed novel character information for $\dagger$ Macroynis casieri, $\uparrow$ Progempylus edwardsi and NHMUK PV OR 41318, allowing these fossils to be coded into a matrix of Recent taxa and phylogenetically assessed for the first time. In these phylogenetic analyses, trichiurids are consistently resolved as a monophyletic 
group nested within a paraphyletic grade of 'gempylids' and we support the term Trichiuroidea for the group as a whole. †Progempylus edwardsi is recovered as deeply nested within Trichiuroidea within the 'gempylid' grade. The isolated braincase previously associated with 'gempylids', NHMUK PV OR 41318, is recovered within the 'gempylid' grade, sometimes in association with Rexea. NHMUK PV P26904 is reassigned from $\uparrow$ Eutrichiurides winkleri to the new genus and species †Macroynis casieri and considered to be Trichiuroidea incertae sedis. Laterally compressed body fossils associated with Trichiuroidea are informally placed within the clade based on phylogenetic patterns of character distribution implied by our analyses.

Acknowledgements. The authors thank Farah Ahmed, Amin Garbout, Rebecca Summerfield, Dan Sykes, Emma Bernard, James MacLaine and Oliver Crimmen for access to the collections and assistance with scanning at the Natural History Museum, London. For access to specimens we also thank Doug Nelson at the University of Michigan Museum of Zoology, Caleb McMahan at the Field Museum of Natural History and Christine Thacker, Rick Feeney and Javier Gago at the Los Angeles County Museum of Natural History. We thank Thodoris Argyriou for his help in deriving the Greek name of Macroynis. This study includes data produced in the CTEES facility at University of Michigan, supported by the Department of Earth \& Environmental Sciences and College of Literature, Science, and the Arts. This research was supported by a NERC studentship to HB on the DTP Environmental Research (NE/L0021612/1), a Leverhulme Project Grant (RPG-2012-658) and Leverhulme Prize (PLP-2012-130), both to MF, and a Junior Research Fellowship from Christ Church, Oxford, to SG. The authors would like to thank Eric Hilton and an anonymous reviewer for their thorough and constructive comments on an earlier version of this manuscript, and to Sally Thomas for her help with copy editing and production.

\section{DATA ARCHIVING STATEMENT}

Data for this study (including character list, matrix, a Mimics file, .vol file, .ply files and other information) are available in the Dryad Digital Repository: https://doi.org/10.5061/dryad.7722q.

This published work and the nomenclatural acts it contains, have been registered in ZooBank: http://zoobank.org/References/C034514B7532-44D0-AA59-D9D687A4CC9F.

Editor. Lionel Cavin

\section{REFERENCES}

AFSARI, S., YAZDI, M., BAHRAMI, A. and CARNEVALE, G. 2014. A new deep-sea hatchetfish (Teleostei: Stomiiformes: Sternoptychidae) from the Eocene of Ilam, Zagros Basin, Iran. Bollettino Della Società Paleontologica Italiana, 53 (1), 27-37.
ALFARO, M. E., FAIRCLOTH, B. C., HARRINGTON, R. C., SORENSON, L., FRIEDMAN, M., THACKER, C. E., OLIVEROS, C. H., ČERNÝ, D. and NEAR, T. J. 2018. Explosive diversification of marine fishes at the CretaceousPalaeogene boundary. Nature Ecology \& Evolution, 2, 688-696.

ARAMBOURG, C. 1927. Les poissons fossiles d'Oran. Matériaux Pour la Carte Géologique de L'Algérie, 1re Série: Paléontologie, 6, 1-298.

— 1943. Note préliminaire sur quelques Poissons fossiles nouveaux. Bulletin de la Société Géologique de France, 43, 281-288.

_ 1967. Les poissons oligocene de l'Iran. Notes et Mémoires sur le Moyen Orient, 8, 1-210.

— and SIGNEUX, J. 1952. Les vertébrés fossiles des gisements de phosphates (Maroc-Algérie-Tunisie). Mémoires $d u$ Service Géologique Marocco, 92, 1-372.

BANNIKOV, A. F. 1985. Fossil scombrids of the USSR. Trudy Paleontologicheskogo Instituta: Akademiya Nauk SSSR, 210, 1111.

- 2005. A new species of the snake mackerel genus Abadzekhia (Perciformes, Gempylidae) from the lower Oligoene of the Northern Caucasus. Paleontologicheskii Zhurnal, 1, 65-68.

- 2010. Fossil vertebrates of Russia and adjacent countries: Fossil Spiny Rayed Fishes (Teleostei, Acanthopterygii). GEOS, Moscow. [in Russian]

- 2017. New data on the morphology of the snake mackerel Abadzekhia tarletskovi Bannikov (Perciformes, Gempylidae) from the Lower Oligocene of the Northern Caucasus. Paleontological Journal, 39 (1), 62-65.

— and FEDOTOV, V. F. 1989. On the taxonomic position of the Perciform Genera Lednevia and Abadzekhia from the Maikopian of the Southern USSR. Byulleten, Moskovskogo Obschestva Ispytateliy Prirody, Odtel Geologicheskii, 64, 85-90.

— and PARIN, N. V. 1995. Description of the new species of scabbardfish (Aphanopinae: Trichiuridae) from the Middle Eocene of the northern Caucasus, with restoration of the validity of the fossil genus Anenchelum. Journal of Ichthyology, 35, 183-192.

BECKETT, H. T. and FRIEDMAN, M. 2016. The one that got away from Smith Woodward: cranial anatomy of Micrornatus (Acanthomorpha: Scombridae) revealed using computed microtomography. Geological Society, London, Special Publications, 430, 337-353.

_ GILES, S., JOHANSON, Z. and FRIEDMAN, M. 2018. Data from: Morphology and phylogenetic relationships of fossil snake mackerels and cutlassfishes (Trichiuroidea) from the Eocene (Ypresian) London Clay Formation. Dryad Digital Repository. https://doi.org/10.5061/dryad.7722q

BETANCUR-R, R., BROUGHTON, R. E., WILEY, E. O., CARPENTER, K., LÓPEZ, J. A., LI, C., HOLCROFT, N. I., ARCILA, D., SANCIANGCO, M., CURETON II, J. C. and ZHANG, F. 2013. The tree of life and a new classification of bony fishes. PLOS Currents Tree of Life, published online 18 April. https://doi.org/10.1371/currents.tol.53ba 26640df0ccaee75bb165c8c26288

- Wiley, E. O., ARRATIA, G., ACERO, A., BAilly, N., MiYA, M., LeCointre, G. and ORTí, G. 2017. Phylogenetic classification of bony fishes. BMC Evolutionary Biology, 17, 1-162. 
BLAINVILLE, H. D. DE 1818. Sur les ichthyolites ou les poissons fossiles. 310-395. In Nouveau dictionnaire d'histoire naturelle, 27. Deterville, Paris.

BONDE, N. 2008. Osteoglossomorphs of the marine Lower Eocene of Denmark-with remarks on other Eocene taxa and their importance for palaeobiogeography. Geological Society, London, Special Publications, 295, 253-310.

- ANDERSON, S., HALD, N. and JAKOBSEN, S. 2008. Danaekra - Denmark's best fossils. Gyldendal, Copenhagen, 226 pp. [in Danish]

CARNEVALE, G. 2006. A new snake mackerel from the Miocene of Algeria. Palaeontology, 49, 391-403.

CARPENTER, K. E., COlletTe, B. B. and RUSSO, J. L. 1995. Unstable and stable classifications of scombroid fishes. Bulletin of Marine Science, 56 (2), 379-405.

CASIER, E. 1944. Contributions à l'étude des poissons fossiles de la Belgique. V. - Les genres Trichiurides Winkler (s.str.) et Eutrichiurides nov., leurs affinités respectives. Bulletin du Musée royal d'histoire naturelle de Belgique, 20, 1-9.

— 1946. La faune ichthyologique de l'Yprésien de la Belgique. Mémoires du Musée royal d'histoire naturelle de Belgique, 104, $1-267$.

_ 1966. Faune ichthyologique du London Clay (2 vols: text \& atlas). Trustees of the British Museum (Natural History), London, $136 \mathrm{pp}$.

COllette, B. B., POTThofF, T., RiChaRd, W. J., UEYANAGI, S., RUSSO, J. L. and NISHIKAWA, Y. 1984. Scombroidei: development and relationships. 591-620. In MOSER, H. G., RICHARDS, W. J., COHEN, D. M., FAHAY, M. P., KENDALL, A. W. Jr and RICHARDSON, S. L. (eds). Ontogeny and systematics of fishes. American Society Ichthyology \& Herpetology Special Publication, 1.

DANILTSHENKO, P. G. 1960. Bony fishes of the Maikop deposits of the Caucasus. Trudy Paleontologicheskogo Instituta: AN SSSR, 78, 3-207.

— 1962. Fishes of the Dabakhanskaya formation of Georgia. Paleontologicheskii Zhurnal, 1, 111-126. [in Russian]

— 1980. Order Perciformes. 115-169. In NOVITSKAYA, L. I. (ed.) Iskopayemye kostistye ryby SSSR. Trudy Paleontologicheskogo Instituta Akademii Nauk SSSR, 178.

DARTEVELLE, E. and CASIER, E. 1959. Les poissons fossiles du Bas-Congo et des régions voisines. Annales du Musée du Congo Belge, A: Mineralogie, Géologie, Paléontologie Série 3, 2, 201-256.

DRUMMOND, A. J. and RAMBAUT, A. 2007. BEAST: Bayesian evolutionary analysis by sampling trees. BMC Evolutionary Biology, 7, 214.

DZHAFAROVA, ZH. D. 1988. Predstavitel' semeistva Trichiuridae s otolitom $v$ khadumskikh otlozheniyakh Apsheronskogo poluostrova. Manuscript dep. VINITI, no. 7581-C, Baku (Azerbaijan).

FRIEDMAN, M., BECKETT, H. T., ClOSE, R. A. and JOHANSON, Z. 2016. The English Chalk and London clay: two remarkable British bony fish Lagerstätten. Geological Society, London, Special Publications, 430, 165-200.

FUJITA, K. 1990. The caudal skeleton of teleostean fishes. Tokai University Press, Tokyo, 897 pp.

GAGO, F. J. 1997. Character evolution and phylogeny of the cutlassfishes: an ontogenetic perspective (Scombroidei: Trichiuridae). Bulletin of Marine Science, 60, 161-191.
1998. Osteology and phylogeny of the cutlassfishes (Scombroidei: Trichiuridae). Contributions in Science, Natural History Museum of Los Angeles County, 476, 1-79.

GILL, T. N. 1862. On the limits and arrangements of the family of scombroids. Proceedings of the Academy of Natural Sciences of Philadelphia, 14, 124-127.

GIUSBERTI, L., BANNIKOV, A., GALAZZO, F. B., FORNACIARI, E., FRIELING, J., LUCIANI, V., PAPAZZONI, C. A., ROGHI, G., SCHOUTEN, S., SLUIJS, A., BOSELLINI, F. R. and ZORZIN, R. 2014. A new Fossil-Lagerstätte from the Lower Eocene of Lessini Mountains (northern Italy): a multidisciplinary approach. Palaeogeography, Palaeoclimatology, Palaeoecology, 403, 1-15.

GREGOROVA, R. 2010. Osteological and morphological analysis of the scabbardfish Anenchelum glarisianum BLAINVILLE, 1818 (Trichiuridae) from the Menilitic Formation of the Moravian part of West Carpathians (Oligocene, Rupelian). Acta Musei Moraviae, Scientiae Geologicae, 95, 141-149.

HARRINGTON, R. C., FAIRCLOTH, B. C., EYTAN, R. I., SMITH, W. L., NEAR, T. J., ALFARO, M. E. and FRIEDMAN, M. 2016. Phylogenomic analysis of carangimorph fishes reveals flatfish asymmetry arose in a blink of the evolutionary eye. BMC Evolutionary Biology, 16, 224.

HUELSENBECK, J. P. and RONQUIST, F. 2001. MRBAYES: Bayesian inference of phylogenetic trees. Bioinformatics, 17, 754-755.

JOHNSON, G. D. 1986. Scombroid phylogeny: an alternative hypothesis. Bulletin of Marine Science, 39, 1-41.

— and PATTERSON, C. 1993. Percomorph phylogeny: a survey of acanthomorphs and a new proposal. Bulletin of Marine Science, 52, 554-626.

KOHNO, H. 1984. Osteology and systematic position of the butterfly mackerel, Gasterochisma melampus. Japanese Journal of Ichthyology, 31, 268-286.

LEAPLEY, W. T. 1952. The Cranial Osteology of the Blue-fish: Pomatomus saltatrix (Linnaeus). Unpublished $\mathrm{PhD}$ Dissertation, The George Washington University, Washington DC, 65 pp, 3 pl.

LERICHE, M. 1905. Les Poissons Éocènes de la Belgique. Mémoires du Musée royal d'histoire naturelle de Belgique, 11/3, 51-228.

— 1908. Note préliminaire sur des Poissons nouveaux de l'Oligocène belge. Bulletin de la Société belge de géologie, de paléontologie et d'hydrologie, Proces-Verbaux, 22, 378-384.

- 1910. Les poissons Oligocènes de la Belgique. Vol. 5. Polleunis \& Ceuterick, Bruxelles.

MENNER, V. V. 1949. Class Pisces. Fishes. Atlas Rukovodyashchikh Form Iskopayemykh Faun SSSR, 13, 346-360.

MIYA, M., FRIEDMAN, M., SATOH, T. P., TAKESHIMA, H., SADO, T., IWASAKI, W., YAMANOUE, Y., NAKATANI, M., MABUCHI, K., INOUE, J. G. and POULSEN, J. Y. 2013. Evolutionary origin of the Scombridae (tunas and mackerels): members of a paleogene adaptive radiation with 14 other pelagic fish families. PLoS One, 8, e73535.

MONSCH, K. A. 2000. The phylogeny of the scombroid fishes. Unpublished $\mathrm{PhD}$ thesis, University of Bristol, $395 \mathrm{pp}$.

2005. Revision of the scombroid fishes from the Cenozoic of England. Transactions of the Royal Society of Edinburgh: Earth Sciences, 95, 445-489. 
- and BANNIKOV, A. F. 2012. New taxonomic synopses and revision of the scombroid fishes (Scombroidei, Perciformes), including billfishes, from the Cenozoic of territories of the former USSR. Earth \& Environmental Science Transactions of the Royal Society of Edinburgh, 102, 253-300.

MÜLLER, J. 1845. Über den Bau und die Grenzen der Ganoiden, und über das natürliche System der Fische. Arch Naturgesch, 11, 91-141.

NAKAMURA, I. and FUJII, E. 1983. A new genus and species of Gempylidae (Pisces: Perciformes) from Tonga Ridge. Seto Marine Biological Laboratory, 27, 173-191.

- and PARIN, N. V. 1993. Snake Mackerels and Cutlassfishes of the World (families Gempylidae and Trichiuridae): An Annotated and Illustrated Catalogue of the Snake Mackerels, Snoeks, Escolars, Gemfishes, Sackfishes, Domine, Oilfish, Cutlassfishes, Scabbardfishes, Hairtails, and Frostfishes Known to Date. Food \& Agriculture Organization of the United Nations, FAO Fisheries Synopsis, 125, 1-136.

NEAR, T. J., DORNBURG, A., EYTAN, R. I., KECK, B. P., SMITH, W. L., KUHN, K. L., MOORE, J. A., PRICE, S. A., BURBRINK, F. T., FRIEDMAN, M. and WAINWRIGHT, P. C. 2013. Phylogeny and tempo of diversification in the superradiation of spiny-rayed fishes. Proceedings of the National Academy of Sciences, 110, 12738-12743.

NOLF, D. and STRIN GER, G. L. 1996. Cretaceous fish otoliths-a synthesis of the North American record. 433-459. In ARRATIA, G. and VIOHL, G. (eds). Mesozoic fishes: systematics and paleoecology. Friedrich Pfeil, Munich.

ORREll, T. M., COllette, B. B. and JOHnSON, G. D. 2006. Molecular data support separate scombroid and xiphioid clades. Bulletin of Marine Science, 79, 505-519.

PARIN, N. V. and ASTAKHOV, D. A. 2007. New fossil fish Musculopedunculus micklichi (Trichiuroidei) from the Lower Oligocene of Germany. Journal of Ichthyology, 47, 547-554.

— and BECKER, V. E. 1972. Materials on taxonomy and distribution of some trichiuroid fishes (Pisces, Trichiuroidae: Scombrolabracidae, Gempylidae, Trichiuridae). Transactions of the P.P. Shirshov Institute of Oceanology, 93, 110-204.

PATTERSON, C. and ROSEN, D. E. 1977. Review of ichthyodectiform and other Mesozoic teleost fishes and the theory and practice of classifying fossils. Bulletin of the American Museum of Natural History, 158, 81-172.

POTTHOFF, T., KELleY, S. and JAVECH, J. C. 1986. Cartilage and bone development in scombroid fishes. Fisheries Bulletin, 84, 647-678.

PROKOFIEV, A. M. 2002. A new genus of cutlassfish from the Upper Paleocene of Turkmenistan (Scombroidei: Trichiuroidea). Zoosystematica Rossica, 11, 229-233.

REGAN, C. T. 1909. On the anatomy and classification of the scombroid fishes. Annals \& Magazine of Natural History, Series $8,3,66-75$.
ROSEN, D. E. 1973. Interrelationships of higher euteleosteans. 397-513. In GREENWOOD, R. S., MILES, R. S. and PATTERSON, C. (eds). Interrelationships of fishes. Academic Press, London.

RUSSO, J. L. 1983. Interrelationships of the gempylid fishes (Teleostei, Scombroidei). Unpublished PhD thesis, The George Washington University, Washington, DC, 249 pp.

SAUVAGE, H.-E. 1873. Mémoire sur la faune ichtyologique de la période tertiaire, et plus spécialement sur les Poissons fossiles d'Oran (Algérie) et sur ceux découverts par M. R. Alby à Licata en Sicile. Annales des Sciences Géologiques, 4, 1-272.

SCHWARZHANS, W., BECKETT, H. T., SCHEIN, J. and FRIEDMAN, F. 2018. Computed tomography scanning as a tool for linking the skeletal and otolith-based fossil records of teleost fishes. Palaeontology, published online 21 February. https://doi.org/10.1111/pala.12349

STRINGER, G. L., OMAN, L. D. and BADGER, R. F. 2016. Woodbury Formation (Campanian) in New Jersey yields largest known Cretaceous otolith assemblage of teleostean fishes in North America. Proceedings of the Academy of Natural Sciences of Philadelphia, 165, 15-36.

SWOFFORD, D. L. 2003. PAUP*. Phylogenetic analysis using parsimony ( ${ }^{*}$ and other methods). v. 4. Sinauer Associates, Sunderland, MA.

TRAPANI, J. 2001. Position of developing replacement teeth in teleosts. Copeia, 1, 35-51.

TUCKER, D. W. 1956. Studies on the trichiuroid fishes-3. A preliminary revision of the family Trichiuridae. Bulletin of the British Museum (Natural History) Zoology, 4, 6-131.

WHITE, E. I. 1931. From the thanet sands to the basement bed of the London Clay. The vertebrate Faunas of the English Eocene. British Museum (Natural History), London, 1, 1-121.

WINKLER, T. C. 1876. Deuxième mémoire sur des dents de poissons fossiles du terrain bruxellien. Archives du Musée Teyler, 4, 16-48.

WOODWARD, A. S. 1891. Catalogue of fossil fishes in the British Museum (Natural History). Part II. Containing the Elasmobranchii (Acanthodii), Holocephali, Ichthyodorulites, Ostracodermi, Dipnoi, and Teleostomi (Crossopterygii and Chondrostean Actinopterygii). Trustees of the British Museum (Natural History), London, 567 pp, 16pls.

1901. Catalogue of fossil fishes in the British Museum (Natural History). Part IV. Containing the Actinopterygian Teleostomi of the Suborders Isospondyli (in Part), Ostariophysi, Apodes, Percesoces, Hemibranchii, Acanthopterygii, and Anacanthini. Trustees of the British Museum (Natural History), London, 636 pp, 19 pls.

ZORZIN, R., BANNIKOV, A. F., FORNACIARI, E., GiUsberti, L., PAPAZZONI, C. A. and ROGHI, G. 2011. Il giacimento a pesci e piante fossili dell'Eocene inferiore di Monte Solane (Verona). Bollettino del Museo Civico di Storia Naturale di Verona. Geologia Paleontologia Preistoria, 35, 57-64. 